\title{
Civic Minstrels in Late Medieval England: New Light on Duties and Careers
}

\author{
Richard Rastall \\ University of Leeds \\ Email: g.r.rastall@leeds.ac.uk
}

\begin{abstract}
The publications of the ongoing Records of Early English Drama project since 1979 have made available for the first time much early documentation about minstrels, including the civic minstrels or town waits. While this material leaves many questions unanswered, a more detailed picture of the early history of civic minstrels is emerging. This article focusses on three aspects of that history that have not previously been studied as such: the towns that employed civic minstrels by 1509 , the minstrels' possible special duties in ports, and their employment mobility.
\end{abstract}

Keywords: minstrels; waits; England; Late Middle Ages

\section{Introduction}

Study of the early history of civic minstrels in England (commonly known as town waits or town pipers) has long been held back by a lack of source material; ${ }^{1}$ but with the publication of Records of Early English Drama (REED) since 1979, there has been a continuous increase in available information about minstrelsy in general and the civic minstrels in particular. These show that earlier publications of civic record material were very selective, suppressing duplicate items and rarely specifying what was omitted. The earlier publications sometimes imply that records are missing, or that they do not mention minstrels, when in fact relevant material has survived. The REED volumes are intended to be comprehensive and are now the standard source of information on early drama and minstrelsy in mainland Britain. Where REED does not yet cover a town's records, older publications have been consulted here, but in the knowledge that they may omit important information. ${ }^{2}$

\footnotetext{
${ }^{1}$ I am grateful to an anonymous reader for helpful comments (on which I have acted), and especially to Keith Polk for correspondence leading to many additions and improvements to this article.

The undifferentiated term 'wait' is not used here unless it is clearly in a civic context. Waits-bands of pipers-were employed by individuals, communities and, possibly, in ad hoc groupings arranged by the minstrels themselves.

${ }^{2} \mathrm{See}<\mathrm{http}: / /$ reed.utoronto.ca/> for REED publications and work in progress. The REED volume for Wales shows no civic minstrels by 1509 (but see under Calais, below); in Scotland there were civic pipers at Aberdeen by 1497, Dumbarton by 1498, Edinburgh by 1502 (including the common piper of the Canongate), and Wigtown and Dumfries by 1503. These probably existed much earlier, as REED volumes on Scotland may eventually show. (Items from Dickson and Paul, Accounts of the Lord High Treasurer of Scotland are calendared in Rastall, 'Secular Musicians', II, Appendix D).

I am not aware of any civic minstrels in Ireland by 1509, but Ireland is another field for investigation.
} 
This article presents information on civic minstrels in England up to the accession of Henry VIII in 1509 , a convenient if arbitrary cut-off point for the early period of wait activity. ${ }^{3}$ It updates the list of towns employing civic minstrels by 1509 , and I discuss new insights on the civic minstrels' work in certain ports, and on their migration between employments. ${ }^{4} \mathrm{My}$ main purpose has been to identify civic minstrels and those who, in certain towns, were responsible for passing information to the citizens.

Where records are plentiful it is possible to follow the payment of wages and rewards, the delivery of robes and scutcheons, and the towns' requirements for the minstrels to perform on specified occasions. I have not normally detailed these unless they are immediately relevant to the minstrels' identities, numbers or activities, so the absence of information here does not mean that it is not available; details will be found in the REED volumes and elsewhere, as footnoted. Short references in the notes are expanded in the Bibliography at the end.

\section{Locations}

Minstrels are recorded in some quite small communities as well as in major towns. As records survive in small communities even more patchily than in large commercial towns it is often difficult to decide whether civic minstrels are concerned or not. The distinction was not important at the time, however: a town would employ known and respected local minstrels to perform during the processions and feasts of major saints' days, and the transition to a retained band would depend on need and finances. Only with the award of annual fees and an annual swearing-in did minstrels become official civic employees, and only later was their status confirmed by the giving of livery (cloth liveries and then scutcheons that had to be examined and weighed each year to see that the minstrels had not sold, mislaid or clipped them). ${ }^{5}$ In the records of these events the minstrels are not always named, and there may be several versions of a name, depending on the scribe. ${ }^{6}$ Sometimes, one suspects, the scribes did not know the minstrels' names and used a general term (although this was usually quicker to write anyway): fistulator (i.e. piper), piparius, ministrallus, histrio or vigilis/vigilator in Latin; piper, wait or minstrel in English.

Civic minstrels are sometimes known only through rewards made elsewhere, often raising a problem of terminology, especially in Latin records. For instance, ministralli Coventrie can mean either '[some] minstrels of [i.e. from] Coventry' or 'the minstrels of Coventry' - that is, the official civic minstrels. The distinction may be made by the use of a phrase such as ministralli civitatis Coventrie, but this is rare. ${ }^{7}$ The problem largely disappears when the records are in English and a definite or indefinite article (or no article) is used.

The section on towns below therefore includes places where the records do not clearly refer to minstrels in civic employment. In such cases I have quoted the wording concerned in the hope that other records will eventually clarify the situation. The size of the reward itself can sometimes give an indication of the minstrels' status as liveried or independent, but the reward also depends on the status and rank of a minstrel's employer and on the financial situation of the town making the payment. These variables are difficult to assess. Rewards given by the city of York, for example, fluctuate widely even between minstrels of apparently equal status. ${ }^{8}$ When there is firm evidence of civic employment (robes, scutcheons, etc.) that evidence is noted. The civic minstrels' routine activities and conditions of employment do not generally concern us here.

\footnotetext{
${ }^{3}$ After this point there is much more information on civic minstrels, both because of the better survival of records and because many towns set up civic minstrels in the sixteenth century.

${ }^{4}$ Matters such as liveries, wages and rewards are discussed in Rastall and Taylor, Minstrels and Minstrelsy, ch. 7.

${ }^{5}$ In some towns the minstrels' employment was reviewed every year, which may have been an inducement to good behaviour. In other places this is not clear, although some civic minstrels had careers of forty years or more.

${ }^{6}$ This is only marginally problematic for town minstrels, but see Rastall, 'Minstrels and players', especially pp. $88 \mathrm{f}$.

${ }^{7}$ The York records perhaps make such a distinction: see under Leicester, below.

${ }^{8}$ See the detailed records of rewards in 1446-9: REED York, I, 65-76. Another unknowable variable is the level and length of entertainment.
} 


\section{Special duties in ports}

During the fifteenth century some towns designated their civic minstrels vigiles or spiculatores, terms that suggest some sort of watching brief. The town of Lynn employed its waits in 1432 on condition that they play their instruments through the town on winter nights, and a similar arrangement obtained at Norwich in $1440 .{ }^{9}$ Poole required a patrol morning and evening, though a little later than the period covered here. There are three reasons for paying the waits to patrol the streets at times when outdoor performance-conditions might not be pleasant: for the entertainment of the citizens, to call the time and weather, and to look out for fire and other dangers.

In certain ports the minstrels probably also announced the state of the wind (vital information if the right wind was needed for starting a voyage), although this is explicitly stated only in the case of Sandwich. The description of the Beverley and Exeter minstrels as spiculatores may hint at this extra responsibility (the term means much the same as vigiles or vigilatores). In some cases the minstrels may have been associated with the watchmen who fulfilled this function, rather than undertaking it themselves, but the evidence is unclear. There are some hints (see under Newcastle upon Tyne) that the minstrels were associated with a serjeant at arms, perhaps for security during this important night work. ${ }^{10}$

In several towns a man was employed to blow a horn to call the citizens to a general assembly or to issue a proclamation. The horn-blower was usually separate from the minstrels, but in some cases there was apparently a working relationship between them. In Dover the minstrels were certainly responsible for blowing the horn(s) and for delivering proclamations, but if they called the time, weather and wind they did so as the fistulatores, pipers or waits, not as the horn-blowers who were paid separately for each sounding. ${ }^{11}$ The town of Dover bought two horns in 1370, as did New Romney in 1486/7, probably to give warning of ensuing announcements. ${ }^{12}$ New Romney had no civic minstrels then, so the hornblowers were not musicians.

Clearly there is circumstantial evidence to be explored here: but evidence of what? Horns were used for outdoor noise-making, such as raising the hue-and-cry ${ }^{13}$ or calling the citizens together: they had nothing to do with music. At Dover the pipers were not paid separately for any daily updates on time and weather, although they may have used horns for this as part of their normal waits' duties; whereas at Sandwich in the 1460s (if Leo of Rozmital's secretary is to be trusted), fidicines and tubicines were used in announcing the state of the wind every night. The leggings provided for Walter Wayte at Grimsby in 1396/7 indicate a harsh environment for his nightly work.

There were two separate duties, then, which had a very variable relationship. One was the civic minstrels' work, making music, and the other was a non-musical duty concerned with giving information by day (for announcements and meetings) and by night (time and weather). Quite who did what and when varied from place to place: the issue must be followed up in individual towns through more evidence than is available in REED volumes.

\section{Employment mobility}

The limited records previously available seemed to show that a town minstrel worked in the same placeassumed to be his birthplace-throughout his career. We can now see that career moves were not

\footnotetext{
${ }^{9}$ Rastall, 'Secular Musicians', I, 222-6. Norwich, like York and Beverley, was an inland port on a navigable river. The Lynn waits were to patrol from Michaelmas (29 September) until the Purification (2 February); the start date was changed to All Saints (1 November) in 1433: Green, Town Life, 145; Janssen, 'The Waytes of Norwich', 12.

${ }^{10}$ The Dover records associate the minstrels with a serjeant in livery-payments; see also under Poole and Newcastle upon Tyne. Following such leads will demand the searching of records not published by REED.

${ }^{11}$ The Dover accounts show up to a dozen or so payments for soundings and proclamations each year-far fewer on average-so these do not relate to the daily updating of weather and time information.

${ }^{12}$ Historical Manuscripts Commission (HMC) 5, Appendix, 547.

${ }^{13}$ Rastall, 'Secular Musicians', I, 215-16.
} 
unusual, and that town waits, like other liveried minstrels, sometimes changed their employers. There is little information on the process by which appointments were made, except that some minstrels appear to have applied for a post at Chester in 1484, and the London waits themselves nominated a colleague in 1517/18: it is not surprising that the waits themselves should have views on who, of those available, would make a good recruit. When the potential employee was already in post elsewhere no doubt the matter was settled by negotiation. This would be easier if the two towns concerned were close and linked by a good road, like Sandwich, Canterbury and London, or in easy communication by sea, like the ports of Hull, Lynn and Sandwich (and, by inland extension, Beverley, York and Norwich).

Towns sometimes enquired after, or positively head-hunted, prospective employees. Civic officers were occasionally paid for their expenses in travelling to find minstrels suitable and willing to be the town's waits, as happened at Shrewsbury in 1479/80 and Canterbury in 1505/06. ${ }^{14}$ This strategy was not always successful, perhaps because a considerable financial inducement would be needed to offset the expenses and inconveniences of a move. Given an acceptable financial offer, such arrangements must usually have been made by mutual agreement: but this was not the case when Southampton apparently poached the civic minstrels of Winchester in 1434, paying them $£ 16 s 8 d$ each per annum. This is more than some towns would have paid, and less than others, but it was presumably more than Winchester was willing to pay (records of the Winchester fees have not survived).

Tracing the movement of individuals depends on demonstrable identities, and for this caution is needed: similarity of names is not necessarily enough, even within the limited profession of the town piper. One can see probable minstrel-dynasties, like the Scarletts and the Wykeses, and some of these (such as the Halydays) may interact with families of royal minstrels. In most cases, especially over long chronological periods, it is difficult even to distinguish the generations: but there are certainly examples of brothers working together, and also fathers and sons (when the Christian names may be the same). Where dates of the two employments closely match, the name may relate to one man. This becomes nearcertainty if two or more named men seem to have relocated together. ${ }^{15}$

The records show several cases of relocation, and more may come to light (see the discussions of individual towns, below). Three waits migrated from Winchester to Southampton in 1434, as just noted; Thomas Williamson moved from Lynn to Beverley in 1456/7, and it seems likely that John Wardlow left Beverley around 1447, becoming a wait of Hull by 1454; Robert Speke moved in the opposite direction, from Hull to Beverley, around 1460-4. The relocation of William Watson and John Watson from Beverley to Sandwich between 1467 and 1476 seems certain from the coincidence of names, despite the chronological gap concerned. William Scarlett apparently moved from Sandwich to Canterbury around 1476/7: he is considered further below.

Several waits moved between Canterbury and London. William Raumpayn, a London wait in 1442, apparently moved to Canterbury by 1446/7, and is last heard of there in 1461/2. Most moved in the opposite direction: William Palling and Nicholas Ryppes, London waits in 1501/2, had been waits of Canterbury until 1498/9. Their appointment at London means that the 'Ryppis' listed at Canterbury in 1504/5 was not Nicholas but presumably a relative: and this may be the John Ryppys who ended his career as a London wait in 1517/18, perhaps having followed his older relative (his father?) to London some time after 1505.

An undoubted father-and-son relationship is that of John and William Blewit of Coventry, one of whom may be the London wait who died in 1517/18. Another possible relocation concerns Brese, a wait of Coventry in 1481, who could be the William Breese who was a Shrewsbury wait in 1505/06. The chronological gap makes it just as likely that they were not the same man, although perhaps related. Another identity problem raised by a large chronological gap concerns two waits of York (q.v.), both with former lives at Beverley.

\footnotetext{
${ }^{14}$ Minstrels were also invited for specific occasions, as when Thomas Vyn of Dover rode for minstrels in 1433/4, and when Canterbury needed minstrels to celebrate St Thomas's day.

${ }^{15}$ I know of no liveried female minstrels in England.
} 
Another opening for a town wait was domestic employment: the Canterbury wait Richard Barton left the town's service in 1430 and was working for the archbishop by 1446. Some civic minstrels were temporarily employed at Court. William Scarlett of Canterbury may be one of the men of that name (the elder, the younger) listed among the 'taborets and trumpets' at Richard III's coronation in 1483; another on that occasion, John Bulson, was probably the Beverley wait of that name. ${ }^{16}$ Permanent employment at Court was also possible: John Raffe, one of the king's still minstrels in 1503, was presumably the Canterbury wait of the late 1490 s. $^{17}$

This mobility was not necessarily the norm, and towns sometimes rewarded their long-serving waits with housing, clothes or an annuity. Provision varied, but examples at Coventry, London and York suggest that it kept the recipient free from serious want for his lifetime.

\section{Towns employing civic minstrels by 1509}

This section lists in alphabetical order those towns and cities that employed their own civic minstrels before 1509/10; they are marked on the accompanying map. The list does not claim to be comprehensive, and indeed there are some surprising absences: one might expect important border towns like Berwick and Carlisle, for instance, to employ waits long before the first references in 1503 and 1602/3, respectively. ${ }^{18}$ Even for towns appearing in this list, further investigations are needed. My purpose here is limited, however, and I have not generally noted items of routine payments to established bands (such as the king's rewards to the London waits from the 1490s onwards) unless they give relevant information on names or dates.

Civic minstrels were normally shawmists (fistulatores, pipers, waits) - at first one or two of them. When three became standard, the third probably played the tenor shawm, or bombard. The wealthiest towns might increase this provision by adding either a trumpeter or a fourth piper (London was exceptional in employing even more). It is unlikely that any competent professional minstrel was limited to one instrument, however, and there are some indications here that a minstrel played a second instrument, although the clues are not conclusive.

Civic records were entered by the accounting year, not the calendar year, and this often coincided with the mayoral year, starting on a feast day in the Church calendar. The accounting year is given here as, for instance, 1485/6, the year from some date in 1485 to the day before that date in 1486 . Accounting years could start on a different date in different places, but I have given that information only where it is specifically needed. Regnal years start from the date on which a king began his reign.

\section{Abingdon (Oxfordshire)}

The 'waites of Abyndon' were rewarded by the king on 24 December 1500. The description and the reward $(3 s 4 d)$ suggest that they were civic minstrels.

(Ashbee, Records, VII, 170, from The National Archives (TNA) E101.415.3, fol. 39v.)

\footnotetext{
${ }^{16}$ See Rastall, 'Minstrels of the English Royal Households', 35; Ashbee, Records, VII, 21. William may have joined relatives in royal service; Edmund Scarlett was also among those taborers and trumpeters in 1483; John Scarlett was a trumpeter of the Duke of York, attending at his coronation as Henry VIII, in 1509. Richard III brought many supporters from the north, his main power-base, for his coronation.

${ }^{17}$ 'Still', as opposed to 'loud' minstrels (pipers, trumpeters, drummers), played the quiet instruments, mainly plucked and bowed strings. The possibility of waits becoming still minstrels has yet to be addressed; Richard Barton of Canterbury presumably played a 'still' instrument professionally. In general, though, a specialist still minstrel was employed: the Coventry guilds employed a separate harper even when the waits played for them, and the waits were associated with harpers at Beverley and Shrewsbury (see below). None of these still minstrels is known to have been in regular civic employment.

${ }^{18}$ See below, under Berwick, and REED, Cumberland, 66. Perhaps strong military bases wanted military personnel, rather than civilians, to fulfill the musical and other functions covered by town pipers elsewhere.
} 


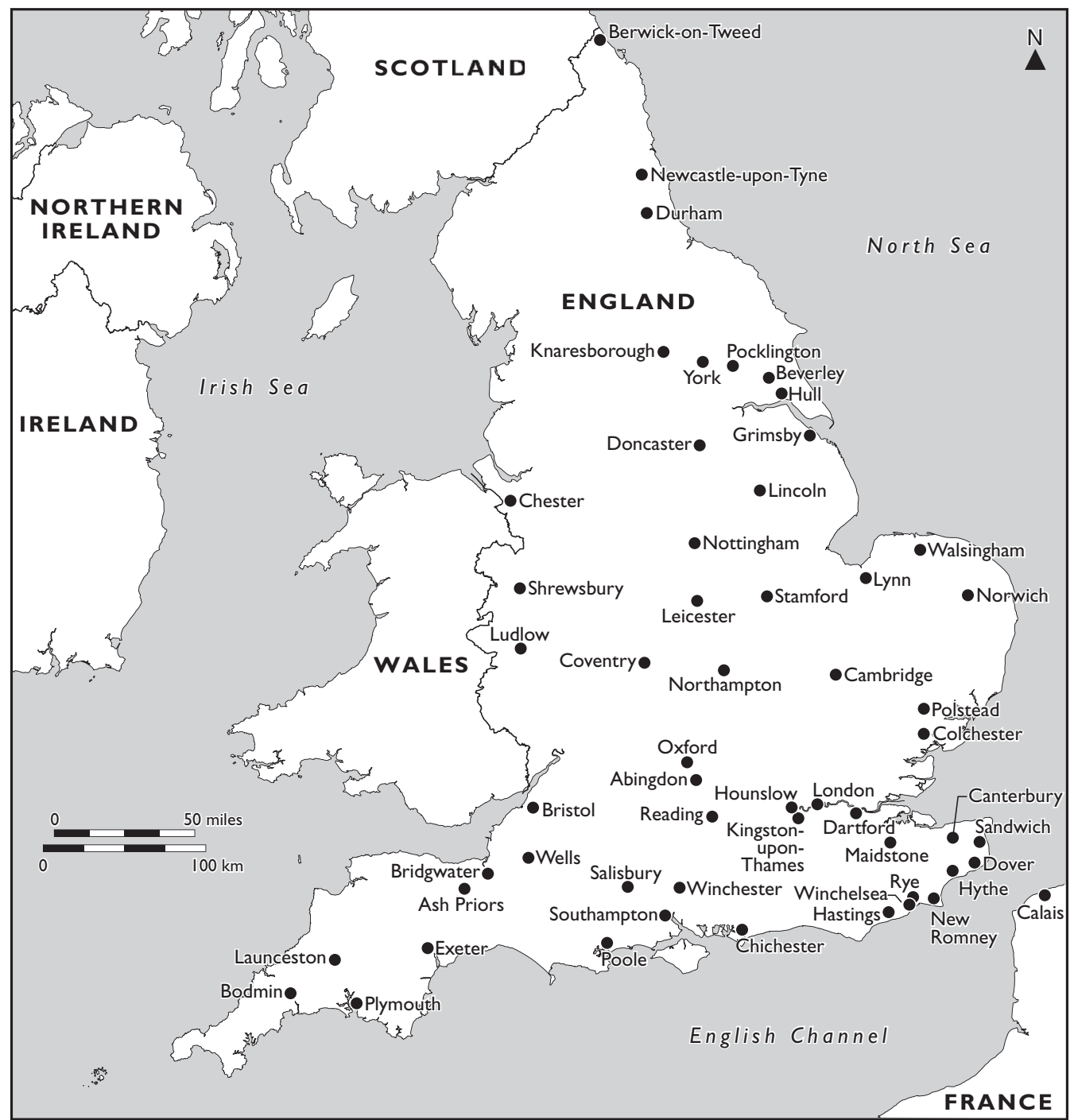

\section{Ash Priors (Somerset)}

The Bridgwater accounts for 1448/9 include $16 d$ paid to the pipers of 'Priouresaysshe' for performing at Corpus Christi. This may indicate civic minstrels.

(REED, Somerset, 41)

\section{Berwick on Tweed (Northumberland)}

James IV, King of Scots, made a gift of nine French crowns, valued at $£ 66 s 0 d$, to the three minstrels of Berwick during the celebrations following his wedding to Margaret Tudor on 8 August 1503. The size of this reward makes it virtually certain that these were civic minstrels. ${ }^{19}$ Berwick, a major military border town, probably employed civic minstrels much earlier.

\footnotetext{
${ }^{19}$ The French crown was the gold coin most commonly circulating in Scotland. The gift of three such coins to each minstrel was perhaps symbolic, related to a practice followed by James at this time. See Williamson, 'The Cult of the Three Kings of Cologne', passim.
} 
(Dickson and Paul, Accounts of the Lord High Treasurer, II, 387, calendared in Rastall, 'Secular Musicians', II, 180)

\section{Beverley (East Riding of Yorkshire)}

The Beverley records first mention civic minstrels-entered as communes histriones ville Beuerlaci-in 1467: but these men were also entered that year under the name of spiculatores, the term for a group employed by the town at least as early as $1405 / 6$ and on to the sixteenth century. As Table 1 shows, this is certainly the group referred to also as ministralli, communes histriones ville Beuerlaci, or simply as histriones. One of the spiculatores appears individually in the records for 1449/50, along with a known harper (see 1445); ${ }^{20}$ and another, described as a piper, was released from gaol in York in November 1445.

Commentators identified the spiculatores, correctly, with the civic minstrels; they also assumed that spiculator meant a watchman, because they 'knew' that the town waits had originally been watchmen. The terminology therefore presented no reason for further investigation. Such an easy acceptance is no longer tenable. ${ }^{21}$ The Beverley spiculatores were certainly civic minstrels from the start, but they may also have had responsibilities special to a port, calling the state of the wind as well as the time and weather generally.

The spiculatores were elected annually at the feast of St Mark (25 April), and their employment was reviewed each year. The records enable us to list the men named in those years for which information remains (Table 1). ${ }^{22}$ Despite good continuity of personnel there was some fluctuation in numbers, and in some years there may have been no spiculatores in post. There is an obvious gap in $1459 / 60$, but there may be others in those years for which records are lost. Most of the spiculatores held office for only a few years, but Wardlow, Hauson and Hesilhed all served for nine years or so.

Table 1. The spiculatores of Beverley, 1405-1509. In each year the group is referred to as the spiculatores; other terms noted here are additional

\begin{tabular}{llll}
\hline $1405 / 6$ & Thomas & Nicholas & \\
\hline $1407 / 8$ & Thomas Muston & and his socius & \\
\hline $1409 / 10$ & Thomas Muston & Peter Facer & John Colvyll \\
\hline $1416 / 17$ & John Gudzer & Stephen Hawson & \\
\hline $1423 / 4$ & John Cloos & Robert his brother & \\
\hline $1433 / 4$ & Robert Schene & William Ricard & John Wardelowe \\
\hline 1436 & Robert Schene & William [Ricard? Johnson?] & \\
\hline 1438 & William Johnson & Symon Herforth & Thomas Seman \\
\hline 1439 & William Johnson & John Wardelow & Robert Cungylton \\
\hline 1440 & John Wardelow & Robert Congilton & Robert Congilton \\
\hline 1441 & Thomas Seman & John Wardlowe & John Grene \\
\hline 1442 & Thomas Seman & John Wardelowe & William Hauson \\
\hline 1443 & John Wardelawe & & \\
\hline
\end{tabular}

\footnotetext{
${ }^{20}$ Some of these records are calendared in Historical Manuscripts Commission (HMC) 54, on pp. 105, 120, 124, 137, $141 \mathrm{f}$ and 143; more are in Wyatt, 'Performance and Ceremonial'.

${ }^{21}$ Rastall and Tayor, Minstrels and Minstrelsy, ch. 6.

${ }^{22}$ I am very grateful to Diana Wyatt, who provided me with draft transcriptions for her forthcoming REED Yorkshire East Riding volume and allowed me to make use of them here. These supersede material in Poulson, Beverlac, HMC 54, and the studies of Beverley records by A. F. Leach.
} 
Table 1. Continued

\begin{tabular}{|c|c|c|c|}
\hline 1444 & John Wardelow & William Hauson & \\
\hline \multirow[t]{2}{*}{1445} & John Wardelowe & William Hauson & Alexander Belle \\
\hline & $\begin{array}{l}\text { [John Whetlay, harper, pays } 3 s 4 d \text { of } \\
6 s 8 d \text { owed: a tenant of the town?] }\end{array}$ & & \\
\hline \multirow[t]{2}{*}{1446} & John Wardelawe & William Hawson & Alexander Belle \\
\hline & $\begin{array}{c}\text { [John Whetlay, harper, fined for bad } \\
\text { behaviour towards the keepers] }\end{array}$ & & \\
\hline 1448 & William Hauson & Thomas Wytton & \\
\hline \multirow[t]{2}{*}{$1449 / 50$} & William Hawson & William Jakson & John Hesilhed, spiculatores \\
\hline & $\begin{array}{l}\text { [William Hawson and John Whetlay, } \\
\text { minstrels, fined for bad behaviour] }\end{array}$ & & \\
\hline $1450 / 1$ & William Hawson & John Hesilhed & \\
\hline 1451 & John Hesilhed & Robert de Celario & Martin Gymer \\
\hline 1452 & John Hesilhed & Robert de Selerio & Martin Gemyr [sic] \\
\hline 1453 & John Hesilhed & Robert de Celario & Martin Gymer \\
\hline 1455 & John Hesylhed & Robert de Sellario & Martin Gymer \\
\hline \multirow[t]{2}{*}{1456} & John Hesilhed & Martin Gymer & Robert de Cellario \\
\hline & $\begin{array}{l}\text { [Robert left the town: Thomas } \\
\text { Williamson of Lynn elected] }\end{array}$ & & \\
\hline 1457 & Martin Gymer & John Hesilhed & Thomas Wyllamson \\
\hline 1458 & John Hesilhed & Thomas Willamson & Martin Gymer \\
\hline 1459 & [none] & & \\
\hline $1460 / 1$ & $\begin{array}{l}\text { [no fees recorded, but } 10 \text { s } 0 d \text { paid for } \\
\text { the spiculatores' Christmas liveries] }\end{array}$ & & \\
\hline 1462 & William Baltizer & John Duraunt & William Watson \\
\hline 1463 & William Baltizer & John Duraunt & William Watson \\
\hline \multirow[t]{2}{*}{1464} & Walter Kirkby & Robert Spek & William Wattson \\
\hline & $\begin{array}{l}\text { [referred to collectively as ministralli, } \\
\text { individually as histrio] }\end{array}$ & & \\
\hline \multirow[t]{2}{*}{1467} & William Watson & John Watson & John Bulson \\
\hline & $\begin{array}{l}\text { [Spiculatores and communes histriones } \\
\text { ville Beuerlaci] }\end{array}$ & & \\
\hline \multirow[t]{2}{*}{1470} & John Bulson & John Levyngston & Robert Richardson \\
\hline & [Histriones and ministralli] & & \\
\hline $1502 / 3$ & three histriones & & \\
\hline
\end{tabular}

\footnotetext{
${ }^{23}$ Whetlay was paid $8 d$ by the city of York on 10 October 1446; the following year he accompanied three Beverley minstrels, probably the spiculatores named here, to York, where they were paid $2 s 0 d$ in early 1447, on or just before St Valentine's day. See REED, York, 69.
} 
Two Beverley spiculatores received wages for the accounting year 1405/6, the first year in which they appear in the records. In 1438, when there were three waits, they had a boy as a servant, lodged with Symon Herforth. ${ }^{24}$ The boy was still employed in $1440 .{ }^{25}$

The spiculatores wore scutcheons from 1423. Shields and chains were repaired and remade several times, ${ }^{26}$ so the surviving scutcheons and chains now in the Guildhall at Beverley are not in their fifteenthcentury state. Cloth liveries to the spiculatores were rather later, and not recorded until 1502/3, when the three histriones were given nine yards of tawney (light brown) cloth for their uniforms for the year. ${ }^{27}$ Four of the five minstrels on the minstrels' pillar in St Mary's church wear tawney tunics, but it is unlikely that they are specifically the Beverley spiculatores. ${ }^{28}$

Four spiculatores appear in other records, assuming that the identities can be considered established by the names. For Robert Shene and Robert Congilton, see under York, below; and John Bulson has already been mentioned. John Wardlow, spiculator from 1438 until 1446 or 1447, may be the 'pyper' of that name among 81 Beverley men released from prison in York castle by a warrant dated 12 November $1445 .^{29}$ Wardlow apparently moved to Hull within a year or two. ${ }^{30}$

(REED, Yorkshire, East Riding)

\section{Bodmin (Cornwall)}

A payment to waits in the town accounts for 1503/4 may refer to Bodmin's own minstrels. The next reference to 'the waytes', in 1519/20, uses much the same wording but treats the reward as a regular annual event. It seems likely that the Bodmin waits existed at least as early as $1503 / 4$, and almost certainly before 1519/20.

(REED, Dorset and Cornwall, 470, 472)

\section{Bridgwater (Somerset)}

The Common Bailiffs' accounts for 1455/6 show a payment of $7 s 10 d$ for tunic(s) for the piper(s). The payment is generous for a single minstrel, perhaps on the low side for two.

(REED, Somerset, 41)

\section{Bristol (Gloucestershire until 1373, then the County of Bristol)}

The four Minstrels del ville were among civic officials given annual liveries by an ordinance dated 14 December 1391: this is the earliest date we have for civic minstrels at Bristol. From the mid-fifteenth century, and periodically to $1518 / 19$, there were regularly four un-named mayor's minstrels: and four 'Waites de Bristoll' were at the mid-day meals on 4, 5 and 6 January 1508 during the Duke of Buckingham's Epiphany celebrations. ${ }^{31}$ In Bristol itself the term 'waytes'-perhaps the town minstrels, although this is not made explicit-is found first in the records of the St George's day celebrations of 1518/19.

The 'mynstrellis of bristowe', probably that city's waits, were paid $20 d$ by the town of Bridgwater in $1495 / 6 .^{32}$

(REED, Bristol, 6, 7, 10 and 26; REED, Somerset, 42)

\footnotetext{
${ }^{24}$ HMC 54th report, 120.

${ }^{25}$ HMC 54th report, 124.

${ }^{26}$ Allison, History, 197; and HMC 54th report, 161 and 105; 161; $120 \mathrm{f}$ and 124; and 135. For descriptions of the badges in 1464 and 1466, see HMC 54th report, 142.

${ }^{27}$ Poulson, Beverlac, 267.

${ }^{28}$ See Merryweather, 'Pillar' for an opinion that their scutcheons are those of the York waits.

${ }^{29}$ Calendar of the Patent Rolls (CPR), Henry VI, vol. 4 (1441-6), 421. A Yorkist insurrection?

${ }^{30}$ Information from Diana Wyatt in a personal communication, 30 May 2015.

${ }^{31}$ REED, Cumberland, Westmorland, Gloucestershire, 357-8; Gage, Extracts, $311 \mathrm{f}$.

${ }^{32}$ REED, Somerset, 42 .
} 


\section{Calais (English possession in France)}

An entry for a reward of $12 d$ 'to a ministrall of Cales' in the Dover accounts for 1467/8 may be for a civic minstrel. The waits of Calais are otherwise not known until well into the sixteenth century, although Dover rewarded various entertainers from the town during the fifteenth century. Sandwich rewarded the histriones Galearum in 1465/6, ${ }^{33}$ which REED translates as entertainers from Wales.

(REED, Kent, Diocese of Canterbury)

\section{Cambridge}

The Corpus Christi Guild records show that the pipers Robert, John and Thomas, together with Robert's wife Alice and Thomas's wife Imania, were admitted to the guild in 1349/50. There is no reason to think that they were employed by the town: but there was a shawm band in Cambridge then, and payments to fistulatores occur at intervals in the next few years. A payment by King's Hall 'to a (or the) common minstrel' (communi histrioni) is probably for a civic minstrel, and similarly a payment 'to minstrels of [the] town' (histrionibus ville) in 1388/9, a wording repeated in 1390/1 and on several occasions in later years. A payment 'to pipers of the town' (fistulatoribus ville) in 1402/3 also looks promising, but without the town's own records it is impossible to be sure that these items refer to civic minstrels. The Town Treasurer's accounts (1423/4 onwards) do not identify any civic minstrels: in fact, payments to various groups of minstrels suggest that the town relied on independent minstrels and those of visiting nobles for music that civic minstrels would normally provide.

From 1445/6 onwards there are a few payments in the Peterhouse records 'to trumpeters of the town' (tubicinis ville). In 1451/2 there is the first mention (by King's College) of the 'four minstrels of Cambridge'

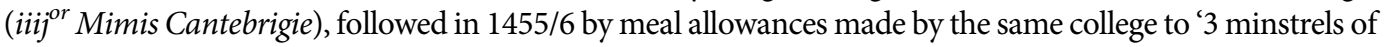
the town of Cambridge' (iij histriones ville Cantabrigie) and in 1456/7 by a payment iij Mimis Cantebrigie.

Any of these could refer to civic minstrels, and such entries continue in the accounts, each institution having its own preferred wording. Civic minstrels were perhaps employed from $c 1450$ or earlier, andless plausibly-they could have been in existence from the start of the fifteenth century. Their employment is certain only with payments for annual livery to the town's minstrels in 1483/4 (pro vestura Ministrallorum ville predicte hoc anno) and later. The number of minstrels is unspecified, but the money paid for cloth suggests three; this is confirmed in the accounts for 1498/9, when livery was made to three minstrels, and again in 1511, when the Trinity Guild at Bassingbourn presented a play of St George with the assistance of a minstrel and the three waits of Cambridge. ${ }^{34}$

The Cambridge minstrels had 'Colers' by 1498/9, when the town paid $21 d$ for their repair. (A 'coler' was usually a metal badge hung from the neck ( $c o l)$ by a chain.) The minstrels are here called 'waits' for the first time: 'pro Reparacione de lez Colers histrionium [sic] vocatorum waytes xxj d.'35

(REED, Cambridge, passim.)

\section{Canterbury (Kent)}

The town accounts for 1366/7 include a reward 'given to [the] minstrels of the town' (datum ystrionibus de villa), probably not referring to civic minstrels. The first certain reference to them is in $1401 / 2$, when three silver scutcheons were delivered to them. Cloth liveries are recorded from 1436/7. ${ }^{36}$

\footnotetext{
${ }^{33}$ REED, Kent, Diocese of Canterbury, II, 342, 827. Dawson, 'Kent' also read 'Galearum'.

${ }^{34} \mathrm{On}$ the feast of St Margaret (20 July):Westlake, Parish Gilds, 64; Bridge, 'Town Waits', 81.

${ }^{35}$ REED, Cambridge, I, 74: the item is unfortunately not precisely dated. The repairs may have been carried out in advance of a performance before the king in early September 1498, when he gave them $10 \mathrm{~s} 0 \mathrm{~d}$ : the king rewarded 'the mynstrelles of Cambrige' again, with $6 s 8 d$, on 31 July 1507: Ashbee, Records, VII, 164, from TNA E101.414.16, fol. 38 ; and 184, from TNA E36.214, 179.

${ }^{36}$ The accounting year at Canterbury ran from Michaelmas (29 September).
} 
These records name the minstrels in most years, describing them variously as histrioni or mynstralli; they were known as 'waytes' from 1429/30 onwards and vigiles from 1476/7. In 1479/80 they were described as histriones seu vigiles ('minstrels or vigiles') and thereafter occasionally as histriones et vigiles ('minstrels and vigiles'). These terms may imply separate functions: as vigiles, fulfilling the night-time commitments seen elsewhere or perhaps summoning the citizens for general meetings (as at Dover, below), and as minstrels accompanying the mayor on formal civic occasions.

The men concerned are listed in Table 2. The number of minstrels fluctuated: three was the norm, but difficulties in certain years reduced the band. William Massyng returned his scutcheon on 5 November 1478, having presumably resigned his post, and William Scarlett's name was erased from the entry for 1480/1, when liveries and fees were paid to only two vigiles (John Chaldan and William Pawlyng). In 1488/9 the senior wait,

Table 2. The town waits of Canterbury, 1416-1514

\begin{tabular}{|c|c|c|c|}
\hline $1416 / 17$ & Langle & Thomas Wodeland & William Fordmell \\
\hline $1429 / 30$ & John Langle & Richard Belle & Richard Barton ${ }^{37}$ \\
\hline $1436 / 7$ & John Langle & John Molys & William Makefare \\
\hline $1439 / 40$ & John Lengle & $\begin{array}{l}\text { 'and his colleagues' } \\
\text { (socii) }\end{array}$ & \\
\hline $1440 / 1$ & John Langle & & \\
\hline $1445 / 6$ & John Langle & & \\
\hline $1446 / 7$ & John Lengle & William Rampen & William Jonson \\
\hline $1447 / 8$ & John Langle & William Jonson & William Rampeyn \\
\hline $1448 / 9$ & John Langley & William Jonsson & William Rampeyn \\
\hline $1449 / 50$ & John Langley & & \\
\hline $1461 / 2$ & John Langle & William Rampayn & John Sclough \\
\hline $1467 / 8$ & (cloth liveries $13 \mathrm{~s} 4 \mathrm{~d}$ : minstrels not named) & & \\
\hline $1476 / 7$ & John Chaldan & William Massyng ${ }^{38}$ & \\
\hline $1477 / 8$ & $\begin{array}{l}\text { (liveries and fees for three minstrels vocati le } \\
\text { waytes) }\end{array}$ & & \\
\hline \multirow[t]{2}{*}{$1478 / 9$} & John Chaldan & William Skarlett & William Powlyng \\
\hline & Vigiles Ciuitatis Cantuarie & & \\
\hline $1479 / 80$ & John Chaldan & William Skarlet & William Pawlyng \\
\hline $1480 / 1$ & John Chaldan & William Pawlyng & \\
\hline $1481 / 2$ & John Chaldan & William Pawlyng & $\begin{array}{l}\text { Thomas Pawlyng, } \\
\text { his brother }\end{array}$ \\
\hline $1482 / 3$ & John Chaldan & William Paulyng & Thomas Paulyng \\
\hline $1487 / 8$ & John Chaldan & Thomas Paulyn & William Paulyn \\
\hline
\end{tabular}

\footnotetext{
${ }^{37}$ A Richard Berton was the archbishop's minstrel in 1446/7 and 1452/3: REED, Kent, Diocese of Canterbury, 67, 337.

${ }^{38}$ These minstrels are named for the securities for scutcheons, but also for two tunics for the vigiles: evidently there were only two minstrels that year. Note the use of vigiles for the town minstrels two years later.
} 
Table 2. Continued

\begin{tabular}{|c|c|c|c|}
\hline $1488 / 9$ & John Chaldan & Thomas Paulyn & William Paulyn \\
\hline $1489 / 90$ & John Walker & Thomas Paulyn & William Paulyn \\
\hline $1490 / 1$ & William Pawlyng & William Cuttyng & Nicholas Reps \\
\hline $1491 / 2$ & William Pawlyn & William Cuttyng & Nicholas Reps \\
\hline $1492 / 3$ & William Paylyng & William Cuttyng & Nicholas Reps \\
\hline $1493 / 4$ & William Paulyn & William Cuttyng & Nicholas Reps \\
\hline $1494 / 5$ & William Paulyn & Nicholas Reps & $\begin{array}{l}\text { John }[\text { sic] Cuttyng } \\
\text { and his widow }\end{array}$ \\
\hline \multirow[t]{2}{*}{$1495 / 6$} & William Paulyn & Nicholas Reps & \\
\hline & For one quarter, at $3 s 4 d$, John Rafe, vigilis & & \\
\hline $1496 / 7$ & William Paulyn & John Raffe & Nicholas Ryps \\
\hline $1497 / 8$ & William Pawlyn & John Rawff & Nicholas Ripys \\
\hline $1498 / 9$ & William Paulyn & Nicholas Ryps & \\
\hline $1499 / 1500$ & (no waits mentioned) & & \\
\hline $1500 / 1$ & (three waits, not named) & & \\
\hline $1501 / 2$ & (no names, number not specified) & & \\
\hline $1502 / 3$ & Thomas Pygeon, vigilis, and his colleagues & & \\
\hline $1503 / 4$ & $\begin{array}{l}\text { (wages of the waytes } 40 \mathrm{~s} 0 \mathrm{~d} \text {, so probably three of } \\
\text { them) }\end{array}$ & & \\
\hline $1504 / 5$ & Pygeon & Ryppis & \\
\hline $1505 / 6-1509 / 10$ & No waits recorded & & \\
\hline $1512 / 13$ & $\begin{array}{l}\text { unspecified number of waits (probably three) } \\
\text { rewarded 'at their first comyng' }\end{array}$ & & \\
\hline $1513 / 14$ & $\begin{array}{l}\text { three waits, not named: cloth liveries } \\
\text { at } 30 \mathrm{~s} 0 d\end{array}$ & & \\
\hline
\end{tabular}

John Chaldan, died at about the feast of St John the Baptist (24 June 1489): John Walker was appointed head wait, and the three minstrels returned John Chaldan's scutcheon at the year's end, 29 September. Thomas Paulyn died on St Martin's day (11 November), his scutcheon being returned to the chamberlains on 5 December 1489. He had not been replaced by Christmas, when only two tunics were paid for.

Replacing a civic minstrel was not always easy. After William Cutting died during the year 1494/5 his replacement took office only for the last quarter of 1495/6. After 1504/5, when there were only two waits, there was evidently a major problem, with no waits at all being employed for several years. In 1505/6 Richard Warren was sent 'for to speke with the waytes att Camberege to brynge them to Canterbury'. This was probably not to bring them to Canterbury permanently, but to ensure the proper celebration of the feast of St Thomas, when music would accompany the procession with its various 'sights'. Warren was apparently unsuccessful at Cambridge, but the London waits came-presumably engaged on his way home from Cambridge-and were paid for 'goyng before the wacche' on St Thomas's night. This arrangement was repeated in 1506/7, and again in 1509/10. 
The king's minstrels, like the queen's, were rewarded every year at this time, and during what seems something of a crisis over the waits, rewards to the king's minstrels were recorded in a changed and possibly significant wording. In 1508/9, and again in 1509/10, the reward was made to them venientibus usque Cantuariam - coming 'as far as', or perhaps 'all the way to', Canterbury. Since the king's minstrels regularly visited Canterbury anyway, this may imply that they changed their arrangements to come at a different time from usual and for a specific purpose. This, like the visits of the London waits, was in the nature of a stopgap. The city was able to recruit a new band of three waits at the end of 1512/13, and to employ them in 1513/14.

Like most civic minstrels, the Canterbury waits performed elsewhere. Payments 'to the mynstrellis of Caunterbury' at Dover in $1491 / 2$ and $1500 / 01$ are probably to the waits; similarly the $16 d$ given to 'mynstrellis of Canterbury' on Corpus Christi day at Dover in 1497/8 (although this is a small sum). ${ }^{39}$ The $12 d$ given to ministrell' Cantuar' at Hythe in $1503 / 4$ is more doubtful, since it is a small reward if to more than one liveried minstrel.

(REED, Kent, Diocese of Canterbury)

\section{Chester}

City waits are first mentioned in the Chester records in an order of 1539/40 setting out the city's requirement that they play 'for the worship and pleasure of the Citie' at certain times. This duty had evidently been left to the waits themselves to decide, with unsatisfactory results. Now they were required to perform on specified days and at stated times 'as hath beyn accustomed in tymes past'. It is not known how far back this duty went, but the Chester waits were in existence by 1484 or 1485 , when several minstrels applied for 'the Rowme and charge of the waitmen of the said city' following the death of the wait William Smethley. ${ }^{40}$ There were three waits in 1509/10, when the town of Shrewsbury rewarded them. ${ }^{41}$

(REED, Cheshire including Chester; REED, Shropshire, 168)

\section{Chichester (Sussex)}

The king rewarded 'the waites of Cecetr', probably civic minstrels, with $6 s 8 d$ (the usual royal gift to a group of liveried minstrels) on 25 August 1496.

(Ashbee, Records, VII, 157, from TNA E101.414.6, fol. 44 ${ }^{\mathrm{r}}$ )

\section{The Cinque Ports (Kent and Sussex)}

The Cinque Ports provided the king with ships at the five 'head ports' of Hastings, Romney, Hythe, Dover and Sandwich; Rye and Winchelsea also became head ports. ${ }^{42}$ The Lord Warden of the Cinque Ports was also Constable of Dover Castle. Minstrels attached to the Cinque Ports were not, or not only, the Lord Warden's personal minstrels, as those we know about were attached specifically to Dover (q.v.). ${ }^{43}$ Surviving records are inadequate to show the exact arrangement.

In 1366/7 a trumpeter named Alan was given a banner for his trumpet bearing the arms of the Cinque Ports. He was associated with another trumpeter, Boffet, and a piper, John Rustler. They may have served as the ceremonial minstrels of the Warden of the Cinque Ports, but Dover's civic accounts (q.v. below) name them as the town's servants.

\footnotetext{
${ }^{39}$ Corpus Christi (celebrated on the Thursday after Trinity Sunday and therefore falling between 21 May and 24 June), was a major festival: it included a civic procession and, in some places, dramatic performances.

${ }^{40}$ British Library (BL) MS Harley 2091, fol. $21^{\mathrm{r}}$.

${ }^{41}$ REED, Shropshire, 168.

${ }^{42}$ Cobb, 'Cinque Ports'.

${ }^{43}$ The Lord Warden's personal minstrels do appear in the records of Dover, but always anonymously.
} 
In 1456/7 a minstrel of Romney, Robert Cocke, was also granted leave to wear the arms of the Cinque Ports. He was a luter, and perhaps acted as the Warden's 'still' minstrel.

(REED, Kent, Diocese of Canterbury, II, 737; II, 310)

\section{Colchester (Essex)}

When the Duke of Guelders passed through Colchester in 1390 en route to London he rewarded the 'stat pyperen' of the town. ${ }^{44}$ While this designation may have been an assumption on the part of the accounting clerk, it is unlikely to have been a mistake; so until the REED volume on Essex appears, we may take it as likely that Colchester employed at least two civic pipers by 1390 .

\section{Coventry (Warwickshire)}

The city of Coventry employed four minstrels in 1423, but they must have been in operation much earlier. The record of their employment refers to them having 'as oper haue had afore them' and names them as Matthew Ellerton, Thomas Sendell, William Howton and John Trumper. Evidently this was a shawm-and-trumpet band, but the trumpeter may have been a fairly recent addition to a standard trio of shawms. Whoever had been the senior minstrel, the authorities ordained in 1439 that the trumpeter should 'haue the rule off the whaytes And off hem be cheffe', although it is not clear whether this went with the trumpeter's post or with that particular trumpeter.

One of the first three waits named was the replacement for Richard Waite, who had recently retired with a pension after long service. ${ }^{45}$ Evidently the town minstrels had then been in operation for a considerable time for Richard to have earned a generous annuity from the city, the Trinity Guild and the Corpus Christi Guild. Richard may have been a member of those guilds.

Other waits too became guild members. In 1481 all four waits and their wives were made members of the Smiths' guild, on condition that they 'serve the crafte on corpus christi day for viij s \& theyr dener'. The waits were named as Thomas West, Adam West, John Blewet and 'Brese the wayt'. ${ }^{46}$ Blewet was a member of the Corpus Christi Guild, 1490-6; in 1494 he held a tenement from the guild. Adam West was also a member of the guild, 1494-8. In 1494 'Wyll blewet Wayt', also known as the son of John Blewet, was a member of the Corpus Christi Guild, remaining so until 1501. William had apparently replaced his father as a wait, but John Blewet was not dead: in 1501, and again in 1505, John still held the tenement. If the Blewet who died as a London wait in 1517/18 was a Coventry wait who had moved to London, it was probably William.

(REED, Coventry, passim)

\section{Dartford (Kent)}

The king gave $3 s 4 d$ to 'the waytes of the town' when he was in Dartford on 5 April 1494.

(Ashbee, Records, VII, 153, from BL Add. MS 7099, fol. 16 ${ }^{\text {r }}$ )

\section{Doncaster (West Riding of Yorkshire, now South Yorkshire)}

Allan Pyper and William Pyper were elected 'Pipers or Wayts' in $1457 .{ }^{47}$ No further evidence is known for the Doncaster waits until 1578/9. ${ }^{48}$

\footnotetext{
${ }^{44} \mathrm{I}$ am grateful to Keith Polk for this information, given in Nijsten, Het Hof van Gelre, 124. See also Coelho and Polk, Instrumentalists and Renaissance Culture, 53.

${ }^{45}$ Harris, Coventry Leet Book, 59; also REED, Coventry, 8. There is no proof that Richard was a minstrel, but 'wait' would normally signify that an individual was a shawmist.

${ }^{46}$ REED, Coventry, 64 . Their wives are not named.

${ }^{47}$ Bridge, 'Town Waits', 64.

${ }^{48}$ See the Waits website at <http://www.townwaits.org.uk/history_doncaster.shtml>.
} 


\section{Dover (Kent)}

The surviving records of Dover fall into two main periods, 1365-84 and 1423 onwards. Throughout these periods the town employed a common piper, designated fistulator or piperius in Latin, and 'piper', 'minstrel' or 'wayte' in English. At times this piper was joined by a second piper: both received an annual fee and robe. Their duties as minstrels are not specified, but they were sometimes rewarded at feasts, so a musical function can be assumed. Their names are listed in Table 3 , where one can see an overlap with the records of the Cinque Ports in 1366/7 (but the reward to 'minstrels of the Cinque Ports' in 1383/4 shows that the Ports employed their own minstrels by then). The annual fee (wages, stipend) of the Dover fistulatores was 20 s each throughout the period 1366-1509, usually paid in quarterly instalments of $5 \mathrm{~s}$ but sometimes in part-payments of smaller sums.

The surviving accounts are clearly incomplete, with some years showing no records of pipers being sworn in (which must have happened normally every year), fees being paid for less than a full year, and no payments for liveries. It is however fairly clear that in some years when two pipers were employed one of them did not work for the whole year; and sometimes the piper changed mid-year. This is not easy to work out: pipers are usually named in the records of their swearing-in, but scribes varied in whether or not they named recipients of fees and robes.

A horn was sounded at Dover when the authorities wanted to summon the citizens to a meeting, to hear a proclamation, or to warn of a danger. ${ }^{49}$ The town custumal (1356-7), which prescribed the process of electing a mayor on the feast of the Nativity of the Blessed Virgin (8 September, which was the start and finish of the mayoral and accounting year), required the horn to be sounded in 14 different parts of the town; the early-sixteenth-century custumal says only 'in certeyn places of the towne'. ${ }^{50}$

On some occasions a single horn was sounded, and on others-perhaps more often than the records explicitly say-two horns were blown (but at the same fee, $2 d$ ): the town owned two horns. The men paid to do this are sometimes identified as the vigilatores: when they are named, which is by no means the norm, they can be identified as the town fistulatores. There are no separate stipends recorded for the horn-blowers, probably because the work required varied so much. Their payment was a fee for each occasion: $2 d$ for blowing the horn, and $2 d$ for making a proclamation. ${ }^{51}$

Only a few occasions of horn-blowing were paid for each year: so if announcements of the time, wind and weather were regularly made it was not the responsibility of the horn-blowers per se but of the pipers, acting in their capacity as the town minstrels.

When only a single piper was employed Dover could not provide an adequate minstrelsy for the larger celebrations, and the town probably relied on visiting minstrels. In 1497/8 the town paid $16 d$ 'to Mynstrelles of Canterbury at corpus Christi day', and in 1503/4 16d 'to the waytes of Caunterbury on Sant Georges daye'. Clearly there was no regular arrangement for providing minstrelsy on these important feast days (and one would expect the Canterbury minstrels to be employed at home then).

(REED, Kent, Diocese of Canterbury)

\section{Durham}

Two minstrels of Durham were rewarded at York in 1446: they were given only $8 d$, so were probably not civic minstrels.

(REED, York)

\footnotetext{
${ }^{49}$ Most information about horn-blowing is from the sixteenth century and later: for the Kentish ports, see REED, Kent, Diocese of Canterbury, I, lxxv.

${ }^{50}$ REED, Kent, Diocese of Canterbury, II, 309. One would expect at least one horn-blowing to take place every year, therefore: but this does not show in the records, perhaps due to deficiencies or losses in the documentation.

${ }^{51}$ It is not clear how information was imparted if the fistulator made no proclamation. Perhaps a written notice was nailed up, or perhaps important proclamations were entrusted to another civic servant, perhaps the common clerk (whose emoluments are not listed by REED).
} 
Table 3. The fistulatores of Dover. In most years there are payments for the stipend (fee, salary) of the fistulator (piper: sometimes two of them), the robes of officers, and for sounding the horn. Many of these do not name the recipient and are omitted here unless they help with identification. The fee for a horn-blowing was normally $2 d$, and $2 d$ for making a proclamation. Where the horn-blower can be identified he is the piper: but it seems that a second person could be hired to blow the horn if two were needed.

\begin{tabular}{|c|c|}
\hline $1365 / 6$ & Stipend and livery robe to the piper. ${ }^{52}$ \\
\hline & Gifts to Boffet, John Rustelere and others at the feasts of Corpus Christi and Ascension \\
\hline \multirow[t]{2}{*}{$1366 / 7$} & Gift to Boffet, tubator \\
\hline & $\begin{array}{l}\text { Alan, trompour, given a pennant for his trumpet bearing the arms of the Cinque Ports (among } \\
\text { external expenses, so he was apparently not a servant of the town) }\end{array}$ \\
\hline \multirow[t]{2}{*}{$1370 / 1$} & Two horns bought for the vigilatores \\
\hline & Stipend for the common piper (20s, so only one) \\
\hline $1371 / 2$ & Stipend for the common piper; 1 robe for the piper \\
\hline \multirow[t]{2}{*}{$1372 / 3$} & Two horns sounded for the Burghmote \\
\hline & Year's stipend for one common piper \\
\hline $1373 / 4$ & One common piper \\
\hline \multirow[t]{2}{*}{$1374 / 5$} & William Deghere paid for sounding the horn \\
\hline & One common piper \\
\hline \multirow[t]{4}{*}{$1375 / 6$} & Reward to John Restlere and Salamon, piper \\
\hline & Robe for John Piper (i.e. Restelere) \\
\hline & Gifts to John Piper and others at Christmas and Easter \\
\hline & John Brigham paid for sounding the horn \\
\hline \multirow[t]{3}{*}{$1376 / 7$} & Robe, stipend and reward to John Piper \\
\hline & Robe and stipend (for one quarter) to Hauckyns, piper \\
\hline & Payment to Alan Tromblour for sounding the horn \\
\hline $1378 / 9$ & Stipend, robe and reward to John Piper \\
\hline $1381 / 2$ & Stipend to John Piper \\
\hline \multirow[t]{4}{*}{$1382 / 3$} & Stipend to John Piper \\
\hline & Reward to John Piper (his last appearance by name) \\
\hline & Payment for two soundings of the horn (pro ij cornubus sonandis, $4 d$ ) \\
\hline & Payment for the sounding of two horns (pro sonacione ij cornu, $2 d)^{53}$ \\
\hline $1383 / 4$ & One common piper \\
\hline
\end{tabular}

\footnotetext{
${ }^{52}$ In Latin accounts, the abbreviations conceal the number of pipers, but the stipend (stable at $20 \mathrm{~s}$ for each piper) shows that there was only one. The cost of a livery robe for the piper fluctuated between $5 s$ and $8 s 6 d$ or more per annum.

${ }^{53}$ REED, Kent, Diocese of Canterbury, III, 1096, translates this as two soundings of the horn, but both the payment of $2 d$ and the singular sonacione argue against this.
} 
Table 3. Continued

\begin{tabular}{|c|c|}
\hline [Hiatus] & \\
\hline \multirow[t]{2}{*}{$1423 / 4$} & Stipend and robes to two unnamed fistulatores \\
\hline & Henry Mellere and Gervase Mayster paid for sounding the horn \\
\hline $1424 / 5-1436 / 7$ & Throughout this period Henry Mellere was sworn as fistulator, receiving his robe and stipend \\
\hline \multirow[t]{6}{*}{$1438 / 9$} & Payments to the minstrels of the town \\
\hline & Payment to Henry Mellere, fistulator (stipend?) \\
\hline & Payment to William Brewer \\
\hline & Payment to two minstrels (the fistulatores?) \\
\hline & Stipend owed to the minstrels of the town \\
\hline & Robes to the two fistulatores \\
\hline \multirow[t]{2}{*}{$1439 / 40$} & John Brewer and William Brewer sworn as fistulatores \\
\hline & Wages to John Brewer and William Brewer, fistulatores \\
\hline \multirow[t]{2}{*}{$1440 / 1$} & John Brewer and William Brewer sworn as fistulatores \\
\hline & Wages to John Brewer and William Brewer, fistulatores \\
\hline $1441 / 2$ & William Brewer and John Brewer sworn as town minstrels (ministralli ville) \\
\hline $1442 / 3$ & Thomas Sprot sworn as minstrel of the town (ministrallus ville) \\
\hline \multirow[t]{2}{*}{$1443 / 4$} & Thomas Sprot sworn as minstrel of the town (ministrallus ville) \\
\hline & Wages for the year to Thomas Sprot \\
\hline \multirow[t]{2}{*}{$1444 / 6$} & Thomas Sprot sworn as fistulator \\
\hline & Wages to Thomas Sprot, fistulator \\
\hline $1446 / 7$ & Stipend for Thomas Sprot, fistulator \\
\hline $1447 / 8$ & Stipend to Thomas Sprot, fistulator \\
\hline $1448 / 9$ & [No relevant entry] \\
\hline $1449 / 50$ & Stipend for William [Freman?], fistulator \\
\hline $1450 / 1$ & Money owed to William Freman, fistulator, for his stipend \\
\hline $1451 / 2$ & [No entry] \\
\hline \multirow[t]{3}{*}{$1452 / 3$} & Thomas [Tournour] sworn as fistulator \\
\hline & Stipend to Thomas Tournour, fistulator \\
\hline & Payment to Thomas Tournour, fistulator \\
\hline $1453 / 4$ & Stipend to Thomas Tournour, fistulator \\
\hline \multicolumn{2}{|l|}{ [Hiatus] } \\
\hline \multirow[t]{2}{*}{$1457 / 8$} & Thomas Tournour sworn as fistulator \\
\hline & Stipend to Thomas Tournour \\
\hline
\end{tabular}


Table 3. Continued

\begin{tabular}{|c|c|}
\hline [Hiatus] & \\
\hline $1462 / 3$ & John Brewer sworn as fistulator \\
\hline \multicolumn{2}{|l|}{ [Hiatus] } \\
\hline $1465 / 6$ & One fistulator, paid a stipend and for five horn-blowings \\
\hline $1466 / 7$ & One fistulator, paid a stipend and for four horn-blowings \\
\hline $1467 / 8-1473 / 4$ & Throughout this period John Bukke is sworn as fistulator, paid salary, and for horn-blowings \\
\hline \multirow[t]{5}{*}{$1474 / 5$} & John Bucke named and sworn as fistulator, paid for horn-blowings and given one quarter's fee \\
\hline & Paid to Hochon for piping (2s) \\
\hline & Fee to the 'wayte' $(3 s)^{54}$ \\
\hline & Paid to the 'weyte' for two horn-blowings $(4 d)$ \\
\hline & Fee to 'the weyte' at midsummer ( $3 s 8 d$ ). \\
\hline $1475 / 6-1477 / 8$ & Hugh Hawkyn/Hochon named and sworn as fistulator, paid fees, and paid for horn-blowings \\
\hline $1478 / 9-1481 / 2$ & John Vykery named and sworn as fistulator and paid fees \\
\hline \multirow[t]{4}{*}{$1482 / 3$} & John Heyre and Robert Aleyn named and sworn as common fistulatores \\
\hline & Payments of fees to John Heire, fistulator/'wayte' \\
\hline & Wage-payments to Robert Aleyn/ Robert the wayte \\
\hline & Robes to the two 'waytes' \\
\hline \multirow[t]{9}{*}{$1483 / 4$} & Robert Aleyn named and sworn as fistulator ${ }^{55}$ \\
\hline & Fee to John Heire (5s) \\
\hline & Fee to Robert Aleyn (6s $8 d$ ) \\
\hline & Fee to Robert Aleyn, waite $(5 s)$ \\
\hline & Fee to John Heire $(6 s 8 d)$ \\
\hline & Fee to John Heiere $(5 s)$ \\
\hline & Fee to Robert Aleyn (6s $8 d$ ) \\
\hline & Robes for two 'waytes' \\
\hline & Fee to the two 'waytes' $(11 s 8 d:=5 s+6 s 8 d)$ \\
\hline \multirow[t]{2}{*}{$1484 / 5$} & Robert Aleyn named (and presumably sworn) as fistulator \\
\hline & Payments on his fee to Robert Aleyn $(3 \times 6 s 8 d)^{56}$ \\
\hline
\end{tabular}

\footnotetext{
${ }^{54}$ This and the preceding payment would make up a quarter's wages if they were both to Hochon, but the last quarter's fee, $3 s$ $8 d$, is less than the regular payment of $5 s$. Perhaps Hochon/Hawkyn was employed temporarily in the latter part of the year to cover for Bucke. The term 'wayte' for the piper appears first in 1473/4.

${ }^{55}$ It is curious that John Heire was apparently not sworn in this year, and that each quarter one of the two waits was given a higher fee ( $5 s$ was the norm).

${ }^{56}$ Unless a payment of fees to Aleyn is missing, the extra fee for the three quarters makes up the $5 s$ for the fourth quarter: $3 \times 6 s$ $8 d=4 \times 5 s=20 s$.
} 
Table 3. Continued

\begin{tabular}{|c|c|}
\hline & Robe for 'the wayte' (singular) \\
\hline $1485 / 6-1487 / 8$ & In these years John Heyere was named and sworn as fistulator and received his fees \\
\hline $1488 / 9$ & Fee to the common fistulator (unnamed) \\
\hline $1489 / 90$ & John Heire named and sworn fistulator, received fees and two payments for three horn-blowings \\
\hline $1490 / 1$ & Payments to John Heire for his fee, for two horn-blowings, and for his clothing (8s) \\
\hline \multirow[t]{2}{*}{$1491 / 2$} & John Heyre named and sworn fistulator \\
\hline & Four quarterly payments on his fee to John Heire \\
\hline \multirow[t]{2}{*}{$1492 / 3$} & John Heyre named and sworn fistulator ${ }^{57}$ \\
\hline & Payments to John Heire for his wages and his gown \\
\hline \multirow[t]{2}{*}{$1493 / 4$} & John Heyre named and sworn fistulator \\
\hline & Payments on his fee to John Heire \\
\hline $1494 / 5$ & Wages to John Heire \\
\hline $1495 / 6$ & Fee to John Heire \\
\hline $1496 / 7$ & Payments to John Heire, on his fee and for a horn-blowing and proclamation \\
\hline \multirow[t]{2}{*}{$1497 / 8$} & John Heire and Robert Barret named and sworn fistulatores \\
\hline & Payments, on their wages, to John Heire and Robert Barret \\
\hline \multirow[t]{2}{*}{$1498 / 9$} & John Heire named and sworn fistulator \\
\hline & Payments on his wages to John Heire \\
\hline \multirow[t]{2}{*}{$1499 / 1500$} & John Heire named and sworn fistulator \\
\hline & Payments on his fee to John Heire \\
\hline $1500 / 1$ & Paid for a horn-blowing (unnamed) \\
\hline \multirow[t]{2}{*}{$1501 / 2$} & Paid to John Heire for three horn-blowings \\
\hline & Payments on his wages to John Heire \\
\hline \multirow[t]{3}{*}{$1502 / 3$} & John Heyre named and sworn fistulator \\
\hline & Paid to John Here for two horn-blowings \\
\hline & Payments on his wages to John Here, common fistulator \\
\hline \multirow[t]{4}{*}{$1503 / 4$} & John Here named as fistulator \\
\hline & Paid to John Here, common fistulator, for two (horn) soundings \\
\hline & Payments on his wages to John Here, common fistulator \\
\hline & Paid to him (John Here) for a horn-blowing \\
\hline
\end{tabular}

\footnotetext{
${ }^{57}$ However, a reward of $6 s 8 d$ noted in the accounts of the king's household on 18 October 1492 is to 'the waytes of Dover' in the plural: Ashbee, Records, VII, 152, from BL Add. MS 7099, fol. $8^{\mathrm{r}}$.
} 
Table 3. Continued

\begin{tabular}{ll}
\hline $1504 / 5$ & Robert Tavernere named and sworn as common fistulator \\
\hline $1505 / 6$ & Payments on his fee to the common wait \\
\hline $1506 / 7$ & Payments to 'the comon wayte' on his wages \\
\hline $1507 / 8$ & The year's wages to 'the common wayte' \\
\hline $1508 / 9$ & To the common wait for a horn-blowing and proclamation (4d) \\
\hline & Payments on his wages to the common wait \\
\hline & To Robert [Tavernere] the wait on his wages \\
\hline To the wait for a proclamation (2d) \\
\hline Robe to the wait \\
\hline Robert Tavernere named and sworn as common fistulator, and paid wages \\
\hline Payments to the common wait for horn-blowings and proclamations \\
\hline $1509 / 10$ and beyond: Robert Tavernere remained the 'common fistulator' or wayte.
\end{tabular}

\section{Exeter (Devon)}

Exeter regularly employed a single 'wayte' from 1362/3 onwards: first John Beare; then, from 1364/5, Peter, identified in 1365/6 as Petrus Bylewyne Wayte Ciuitatis predicte (i.e. Exeter); and Thomas Wayte from 1366/7 until 1373/4. In this last year Thomas was paid for only half a year, so he must have retired or moved on mid-year. An increase to at least three of them-John Eget and his colleagues-from 1391/2 indicates no change of function, since they were paid the same annual fee as Thomas, $26 s 8 d$ ( 2 marks). Eget and his colleagues continued in office until at least 1398/9, when they were paid 'for being waits in the city' (essendi Waites in Ciuitate), still at 26s $8 d$ per annum. In 1395/6 John Piper, and perhaps others (the manuscript is damaged), was paid 'for being a wait this year' (essendi Waite isto anno), which effectively tells us that the waits were indeed pipers.

The waits were given cloth liveries from 1401/2 onwards, sometimes with three waits specified. After $1406 / 7$ the livery payments appear irregularly, although the entry for 1417/18 is for the livery 'of the three pipers of the city' (trium fustulatorum Ciuitatis). The records for 1429/30 show that silver scutcheons had been made for them: but scutcheons already existed then, pledges being taken when the waits were elected and sworn in 1427/8. They are named as John Lynde, Hugo Baret and John Dawe, as they are again in 1434/5. In 1439/40 a separate record of pledges names William Paynter, 'one of the minstrels of the city of Exeter'. ${ }^{58}$ The waits' collars (scutcheons and chains) were repaired in 1493/4 at a cost suggesting extensive alteration. ${ }^{59}$ These are probably the collars given to the serjeants-at-arms in 1895 and still part of the city's regalia. ${ }^{60}$

Records of the taking of pledges show the names of the city waits to be as in Table 4 . The records continue to specify three waits until 1500/1, after which no number is given: but as the payment for their fees and liveries remained constant to $1509 / 10$ and beyond, we can assume that there were still three waits to the end of the period covered here. Presumably it was Beaumont, Browne and Merryett

\footnotetext{
${ }^{58}$ REED, Devon, 91, 89, 95, 96.

${ }^{59}$ REED, Devon, 110.

${ }^{60}$ For photographs of the scutcheons, see <http://www.townwaits.org.uk/cogs_exeter.shtml> (accessed 22 July 2019).
} 
Table 4. The town waits of Exeter, 1427-97

\begin{tabular}{|c|c|c|c|}
\hline $1427 / 8$ & John Lynde & Hugo Baret & John Dawe \\
\hline $1434 / 5$ & John Lynde & Hugo Baret & John Dawe \\
\hline $1456 / 7$ & John Dowe & William Halyday & John Agaunt \\
\hline $1457 / 8$ & John Dowe & William Halyday & [robes for only two waits] \\
\hline $1458 / 9$ & William Holeday & [robes for two waits] & \\
\hline $1460 / 1$ & [robes for three waits] & & \\
\hline $1463 / 4$ & John Dawe & William Holyday & John Colarne \\
\hline $1464 / 5$ & Henry Stephenesson & William Filmore & John Agaunt \\
\hline $1467 / 8$ & Richard Stephenson & William Filmore & Robert Beaumont \\
\hline $1471 / 2^{61}$ & William Fylmore & Robert Beaumont & Henry Crede \\
\hline $1472 / 3^{62}$ & William Filmore & Henry Crede & Robert Beaumont \\
\hline $1473 / 4^{63}$ & William Filmore & Henry Crede & Robert Beamont \\
\hline $1474 / 5$ & William Filmore & Henry Crede & Robert Beamont \\
\hline $1477 / 8$ & William Filmore & Henry Crede & Robert Beamont \\
\hline $1482 / 3$ & Robert Beamont & John Joce & Thomas Joce \\
\hline $1491 / 2$ & Robert Bemond & Nicholas Browne & Nicholas Mereke \\
\hline $1496 / 7$ & Robert Beamont & Nicholas Broune & Nicholas Meryett \\
\hline
\end{tabular}

who were rewarded, as 'the mynystrelx of Excester', on 10 October 1497, during the king's visit to Exeter. $^{64}$

(REED, Devon, passim)

\section{Grimsby (Lincolnshire)}

Walter Wayte was provided with cloth livery in 1396/7, and given leggings, suggesting that his post involved being cold or wet, or both. ${ }^{65}$ Possibly he was required to pipe the hours during the night, or to keep watch for fires while performing for citizens around the town. In 1424/5 the town paid for the gown of Walter Waite, histrio ville, so he was certainly considered primarily a musician. The last record of livery for Walter is in 1441/2. If this was the same Walter Wait throughout, he had a long career and must have been aged 60 or so when he retired or died.

In $1421 / 2$ the town allocated $8 s$ for liveries to each of its minstrels, to a maximum of $24 s$, effectively setting three civic minstrels as the norm.

(REED, Lincolnshire, 78, 112; Lancashire, 'Ioly Walte', passim.)

\footnotetext{
${ }^{61}$ In this year the civic minstrels are described as histriones: REED, Devon, 103.

${ }^{62}$ In this year the civic minstrels are described as speculatores: REED, Devon, 103-4.

${ }^{63}$ In this year, and in several subsequent years, the minstrels are described as mimi: REED, Devon, $104 \mathrm{ff}$.

${ }^{64}$ Ashbee, Records, VII, 160, from TNA E101.414.16, fol. $1^{\mathrm{v}}$.

${ }^{65}$ Stokes, 'Waits of Lincolnshire', 77, says $3 s 10 d$. The word here translated 'leggings', cocree (fem. pl.), or more usually ocree, is translated as 'shoes' by REED, but would normally mean greaves, armour for the shins. It could also mean thigh-boots or leggings, however: see the Revised Medieval Latin Word-List under ocree.
} 


\section{Hounslow (Middlesex, now in Greater London)}

In June 1498 Henry VII rewarded the minstrel(s) of Honnesley with $13 s 4 d$, and on 13 September 1499 gave $40 \mathrm{~s} 0 d$ to the minstrel(s) of Honneslow. ${ }^{66}$ These are substantial sums suggesting a group of liveried, and by implication civic, minstrels.

(TNA E101.414.16, fols $31^{\mathrm{v}}$ and $76^{\mathrm{v}}$ : calendared in Rastall, 'Secular Musicians', II, 138 and 141)

\section{Hull (Kingston on Hull: East Riding of Yorkshire)}

Hull had its own town minstrels, which it called 'waytes', at least as early as 1454, when the former Beverley spiculator John Wardlow was named (see under Beverley, above). Another wait, Robert Speke, who was named in around 1460, is probably the man of that name who was a Beverley spiculator in 1464 (and perhaps 1465 and 1466). ${ }^{67}$

\section{Kingston upon Thames (Surrey, now in Greater London)}

The 'waites of London and Kingston' were rewarded by Henry VII with $13 s 4 d$ in February 1498.

(Ashbee, Records, VII, 161, from TNA E101.414.16, fol. 16 ${ }^{\mathrm{r}}$ )

\section{Knaresborough (North Riding of Yorkshire)}

The city of York rewarded a minstrel of Knaresborough with $12 d$ in 1446. The gift is large enough for a liveried minstrel, so he could have been a civic minstrel.

(REED, York)

\section{Launceston (Cornwall)}

The borough accounts from 1445/6 until 1478/9 (after which there is a hiatus in the accounts) link the mayor, his colleagues (socii) and minstrels together in celebrations on the eve of St Mary Magdalene's day (that is, on 21 July); and a payment to a piper named Brown was made in 1450/1. The records do not mention civic minstrels, so these were perhaps from the confraternity attached to St Mary Magdalene's church.

(REED, Dorset and Cornwall, 491-3)

\section{Leicester}

The Leicester waits were probably in existence by 1447, when 'iiij Ministrallis ville Laycestr" were given $2 s$ $0 d$ by the city of York. It is the word ville ('of the town [of Leicester]') that suggests official civic minstrels: a little further down the same list 'iij Ministrallis de Pokelynaton' received only $8 d$ and 'iij ministrallis london" $12 d$, making them less likely to be town waits. ${ }^{68}$ The Leicester minstrels evidently were official when the king gave them $13 s 4 d$ (a normal, if generous, royal gift) on 10 June $1497 .{ }^{69}$

The town received four silver chains in 1503, probably those of the waits returned at the end of a term of office. The borough archives include an undated record of sureties for two waits' chains, which suggests the wearing of chains at a much earlier date, when Leicester employed only two waits. ${ }^{70}$

\footnotetext{
${ }^{66}$ Henry VII's regnal year began on 22 August.

${ }^{67}$ Information from Diana Wyatt, in a private communication of 30 May 2015.

${ }^{68}$ REED, York, I, 69.

${ }^{69}$ Ashbee, Records, VII, 159, from TNA E101.414.6. fol. $76^{\mathrm{r}}$.

${ }^{70}$ Bateson, Leicester, II, 363.
} 
The Nottingham borough accounts for 1500 record that the waits of Leicester attended the Mayor and citizens of Nottingham at the feast of Pentecost. ${ }^{71}$ It was unusual for the waits of one town to perform in another town which employed its own waits (see Dover). The Leicester waits were presumably invited to Nottingham for this occasion, and it would be interesting to know if the three Nottingham waits were also present.

\section{Lincoln}

Lincoln had enough resident minstrels in 1389 to warrant a minstrels' fraternity, ${ }^{72}$ but there is no record of civic minstrels so early. Documentation for town waits starts with a record of 21 April 1422, when the three minstrels of the Mayor of Lincoln received an annual livery-allowance. ${ }^{73}$ The annual cost was limited to $8 s 0 d$ per minstrel, with an overall limit of $24 s$. This is a more generous livery allowance than in many places, but it effectively limited the number of civic minstrels to three (see also under Grimsby, above).

(REED, Lincolnshire)

\section{London}

In 1390 the Duke of Guelders rewarded the city musicians of London (see also Colchester, above), but the original wording of this has not been confirmed. ${ }^{74}$ The London waits certainly existed in $1434 / 5$, when the Merchant Tailors paid 'the waits of London' for their work on St John's day. ${ }^{75}$ In 1442 lez waytes de Citie petitioned the mayor and aldermen for livery, with the city's arms, which would distinguish them as the city's servants. ${ }^{76}$ Lincoln, Lynn and Norwich had all provided their waits with liveries by then, and Coventry did so that same year. ${ }^{77}$ Nine waits are named: John Tassell, William Raumpayn, William Figge, Richard Kendale, John Wikes senior, John Wikes junior, Richard Wikes, Thomas Aleys and Richard Porter. ${ }^{78}$ Nowhere else employed so many civic minstrels. The records of various city companies show that they regularly employed bands of six waits. These, unfortunately, are not identified in any way: they could have been civic minstrels, but there is no reason to think so.

The nine minstrels employed in 1442 put London ahead of anywhere else for lavish musical display: smaller towns employed one or two civic minstrels, three was normal, and only a few, such as Coventry, employed four by the late fifteenth century. London, in fact, may have overreached itself by $1474 / 5$, when an order was made in council limiting the number of city waits to six, specifying a financial limit on their liveries and fees. John Wykes retired in 1495/6, and provision was made for him on account of his 'good service to the city'. He was to be given clothing for life, and the next vacancy at 'Philpot's Alms. ${ }^{79}$ The margin heading for this entry reads 'Reward geuen to Mr wykes Mynstrell for his Age'. This must be John Wykes junior: even if he had become a city wait at the age of 15 in 1442/3 he would be 68 on retirement.

\footnotetext{
${ }^{71}$ Stevenson and Baker, Nottingham, III, 70.

${ }^{72}$ Rastall and Taylor, Minstrels and Minstrelsy, ch. 10.

${ }^{73} \mathrm{Kahrl}$, 'Lincolnshire', 29; REED, Lincolnshire.

${ }^{74}$ I am grateful to Keith Polk for this information, given in Nijsten, Het Hof van Gelre, 124.

${ }^{75}$ That is, 24 June, Midsummer Day. Woodfill, Musicians in English Society, 41.

${ }^{76}$ REED, Civic London, I, 153-4.

${ }^{77}$ See above for Lincoln and for Lynn; also, Stephen, 'Waits', 49, for Norwich; Harris, Coventry Leet Book, 200.

${ }^{78}$ REED, Civic London, I, 153. William Raumpayn may be the man of that name, or a close relative, who was a Canterbury wait from 1446/7 until 1461/2.

${ }^{79}$ REED, Civic London, I, 251. I have found no information on 'Philpot's Alms': it may be a charity started by the city of London with property bequeathed by Sir John Philipot (d. 1384), a successful merchant of the Staple and possibly a member of the Mercers' Company. He was MP for London eight times, 1369-83, sheriff and alderman from 1372, and mayor of London in 1378: he was knighted in 1381 (see The Oxford Dictionary of National Biography). At his death he left considerable property to the city: perhaps almshouses were made of this, or the property sold and almshouses erected with the proceeds.
} 
Another wait whose retirement was marked in this way was John Ryppys, who in 1517/18 was 'infirm and unable to perform his duties': his settlement was an annuity and a place at Philpot's Alms when one became available. ${ }^{80}$ Ryppys's infirmity is not specifically linked to age, so his problem may have been permanent illness or injury. The name is not an error for Nicholas Ryppes, who was a London wait in 1501/2: he could be the Ryppis (no first name given) who was a Canterbury wait in 1504/5 and perhaps a son or other relative of Nicholas, for whom see below.

Also in 1517/18, a deceased wait called Blewet (formerly of Coventry?) was replaced. The other waits nominated one John Frith for the post, and Frith was appointed. ${ }^{81}$

London had a minstrel fraternity in the late fourteenth century, which sought to limit performance by non-members. No doubt protecting their own work, the London waits petitioned the mayor and aldermen in 1501/2 for freedom of the city through the Fellowship of Minstrels, without charge, as had been the custom 'tyme out of mynde'. The waits-currently only five of them-are named as John Marshall, John Brown, William Pallyng, Nicholas Ryppes and John Nayler. Their petition was granted. ${ }^{82}$

They also requested their summer livery, as promised 'at theire commyng to London'. Apparently this was a newly-formed group, but we have no information about the dissolution of the previous group, nor about the recruitment of this one. It may eventually be possible to trace all five, but two of them can certainly be followed from their former employment. William Palling and Nicholas Ryppes had been waits of Canterbury until at least 1498/9: Palling had been in service there since 1478/9, Ryppes since 1490/1.

The waits' earlier petition (1442) implies that as freelance minstrels they could not command enough income, and that the city's livery would improve this situation by making their status known. In granting the petition the Council laid down some conditions that set out the waits' obligations and brought the London waits into line with civic minstrels elsewhere. This suggests a relatively recent organisation (although in that case it is surprising that as many as nine men were involved), but it is impossible to know at what date the waits had originally been instituted.

The waits travelled out of London, including to York, but most often down the principal highway to Canterbury: they were probably there in 1445/6 (histrioni de london) and 1448/9 (histrihones [sic] londonie) $;{ }^{83}$ and in $1504 / 5$, and again in $1505 / 6$, they went there specifically to work on a major Canterbury celebration, St Thomas's eve. ${ }^{84}$

(REED, Civic London, REED, Ecclesiastical London, and REED, Kent, Diocese of Canterbury)

\section{Ludlow (Shropshire)}

Two gowns were bought for 'pe waytes' in 1466/7.

(REED, Shropshire, 74)

\section{Lynn (Norfolk)}

The three waits of Lynn (now King's Lynn) received a fee in 1431, in addition to their livery, and again in 1433. ${ }^{85}$ The king rewarded the waits of Lynn in August 1498. ${ }^{86}$

\footnotetext{
${ }^{80}$ REED, Civic London, I, 348.

${ }^{81}$ REED, Civic London, I, 348.

${ }^{82}$ REED, Civic London, I, 267-8.

${ }^{83}$ The three minstrels of London rewarded at York on 1 June 1447 were surely not the waits, for whom the reward of $12 d$ was too low: see under Leicester.

${ }^{84}$ REED, Kent, Diocese of Canterbury, I, 102.

${ }^{85}$ Green, Town Life, 145.

${ }^{86}$ Ashbee, Records, VII, 163, from TNA E101.414.16, fol. $37^{\mathrm{v}}$.
} 


\section{Maidstone (Kent)}

Robert, pipere de Maydstane, and his colleague were paid $12 d$ by Boxley Abbey in 1353/4, and Robert alone in succeeding years (at $6 d, 8 d$ or $12 d$ ), being joined by his son in 1364/5 (22d) and 1366/7 (18d). Robert last appears in the Boxley records in an undated account from c1385-99 (12d). ${ }^{87}$ The king rewarded 'the shamews of Madeston' with $6 s 8 d$ in $1492 .{ }^{88}$ The rewards to Robert and his fellows are not too small for one or two civic minstrels, so Maidstone may have employed waits by $1353 / 4$ : that paid in 1492 was a normal royal reward for town waits.

(REED, Kent, Diocese of Canterbury; Ashbee, Records, VII, 151, from BL Add. MS 7099)

\section{New Romney (Kent)}

A long history of horn-blowers includes the purchase of two horns in 1486/7. ${ }^{89}$ These were used to draw attention to public announcements and meetings (perhaps, in this port, including the calling of the hours, wind and tides), but there is no apparent connection with musicians. Although rewards to visiting minstrels are normal in these accounts, there are no payments for local civic minstrels up to 1509 .

See under the Cinque Ports for a luter of Romney given the ports' livery.

(REED, Kent, Diocese of Canterbury, passim.)

\section{Newcastle upon Tyne}

The city of York rewarded three minstrels of Newcastle (iij Ministrallis Noui Castri super Tynam) in 1445 and two in 1447. The rewards of $20 d$ and $12 d$, respectively, are commensurate with those to other liveried minstrels attached to gentlemen and knights, and probably refer to civic minstrels. There is no firmer evidence for civic minstrels at Newcastle before 1508, however, when the surviving Chamberlains' accounts begin. Cloth liveries were made to three waits: only Thomas Carr and William Carr are named. In the same year a 'coller' was made for William Carr.

A payment in 1511 to the waits and a serjeant together may indicate that the minstrels worked in tandem with a serjeant at arms accompanying them at night. There are hints of this elsewhere, but nothing definite.

(REED, Newcastle upon Tyne; Fraser, Accounts of the Chamberlains.)

\section{Northampton}

In $1479 / 80$ the town of Shrewsbury paid $3 s 0 d$ to bring a minstrel 'called a wait' from Northampton. This was probably a town minstrel, perhaps drafted in to make good a temporary vacancy at Shrewsbury, but there is no further information. The 'waytes of Northampton' were rewarded by the king in May 1493.

(REED, Shropshire, 154; Ashbee, Records, VII, 152, from BL Add. MS 7099, fol. 10 ${ }^{\mathrm{r}}$ )

\section{Norwich}

The civic minstrels of Norwich are first recorded in 1408, when the Company of St George, virtually the town's governing body, decided to give an annual fee to 'the minstral Wayts of the City'. ${ }^{90}$ It is not known who they were, nor how many of them there were: but when waits were admitted and sworn in 1422 there

\footnotetext{
${ }^{87}$ REED, Kent, Diocese of Canterbury, II, 905-8, passim.

${ }^{88}$ Ashbee, Records, VII, 151, from BL Add. MS 7099, fol. $6{ }^{\mathrm{r}}$.

${ }^{89}$ HMC 5, Appendix, 547.

${ }^{90}$ Stephen, 'Waits', 5. There is as yet no REED volume for Norwich records before 1540. The most recent work is Janssen's 'The Waytes of Norwich' (1978). I am grateful to Rob Glencross, Digital Publishing Assistant at the library of the University of New Brunswick, for facilitating access to a digital image of this thesis, and to ProQuest for allowing that access.
} 
were two of them, named as John Underwood and Roger Jacob. ${ }^{91}$ They were increased to three by 1426/7, when the Treasurer's accounts record payment for the making of three silver skochonys for the minstrels. ${ }^{92}$ Another scutcheon made in 1432/3 marks an increase to four waits, named as Thomas Verdon, John Cros, John Smyth and William Goldryng. ${ }^{93}$ William Spencer, minstrel, was granted livery as a wait of the city on 18 December 1437, but he was probably a replacement. On 10 November 1440 only three waits received livery, named as William Goldryng, John Smyth and John Cros. ${ }^{94}$

Although three waits were the norm in many places and only three were admitted in $1452,{ }^{95}$ Norwich seems to have wanted four. William Warwyck and three others (unnamed) were given winter liveries in $1457 / 8$, an increase that may not have been new (there is a gap in the records, 1440-57). Warwyck resigned his post in 1463/4. A fourth wait was elected in 1466 to join Thomas Barwyck/Berwyck, John Clyfton and John Robynson. William Scarlett was chosen, in preference to one Bele, but his election was reversed and Robert Dikman given the post. The reason for this is not known: Scarlett was given 10s in compensation. ${ }^{96}$

In 1467 four waits were again sworn-John Robynson, Thomas Berwyck and two others, unnamedand four waits regularly appear in the records from 1470 onwards. The waits accompanied Edward IV to France as his minstrels in 1475. Thomas Berwyck must have been one of these: he was removed from office in 1505 on account of his senility, and pensioned (he died in 1508). ${ }^{97}$

Returning to William Scarlett, a man of that name had taken the freedom of the city in 1455, and was presumably well known. At some time before $1488 / 9$ he was a tenant of the city, if it is the same man. Janssen notes that in 1491/2 St George's Guild paid 16d to two minstrels, 'Scarlet and Jamys luter', and suggests that this was Thomas Scarlett, to whom John Reynolds (later a wait) was apprenticed in 1497/8; and that in 1509 one William Scarlett took John Florens as apprentice. There was evidently a family of Scarletts, who may or may not be related to those in London and the south-east.

\section{Nottingham}

The three 'Waytes de Notyngham' were rewarded at York in 1448: their number remained at three into the sixteenth century. ${ }^{98}$ They were given 'colars', presumably scutcheons and chains, which had to be mended in 1496 and so dated from before then. ${ }^{99}$ A record of sureties for these chains in 1502/03 names the waits as Hugh Little, William Chumley (alias William Wayte) and Roger Barker (alias Roger Wayte). ${ }^{100}$

\section{Oxford}

The town probably had its own civic minstrels by 1490/1, when an order for receiving the mayor includes, in a list of town officials, 'ye Mynstrels'.

(REED, Oxford, 35)

\footnotetext{
${ }^{91}$ Stephen, 'Waits', 28. A minstrel called John Underwode was rewarded at York, perhaps on 12 April, in 1448: he seems unlikely to be the same man, but it is possible.

${ }^{92}$ Ashbee, Records, VII, 163, from TNA E101.414.16, fol. $37^{\mathrm{v}}$.

${ }^{93}$ Hudson and Tingey, Norwich, II, 66; and 67; Janssen, 'The Waytes of Norwich', 8.

${ }^{94}$ Janssen, 'The Waytes of Norwich', 10.

${ }^{95}$ Stephen, 'Waits', 28.

${ }^{96}$ Janssen, 'The Waytes of Norwich', 14-15. Bele is unlikely to be the man who was a Beverley wait 20 years earlier.

${ }^{97}$ Janssen, 'The Waytes of Norwich', 15-17, 22. The city hired other minstrels to cover for the waits during their absence, an arrangement seen elsewhere (see under Dover, Leicester).

${ }^{98}$ Stevenson and Baker, Nottingham, II, 379; III, 416 and 320.

${ }^{99}$ Stevenson and Baker, Nottingham, III, 287.

${ }^{100}$ Harris, Coventry, 200; Harris, 359; Stevenson and Baker, Nottingham, II, 287; Stevenson and Baker, Nottingham, III, 90.
} 


\section{Plymouth (Devon)}

The waits received livery of sixteen yards of cloth in 1496/7, which suggests that there were four of them. (REED, Devon, 213)

\section{Pocklington (East Riding of Yorkshire)}

Three minstrels 'de Pokelynaton' were rewarded by the city of York on 31 May 1447. They were probably independent performers, as their reward of $8 d$ would be small for liveried minstrels, even of a small and nearby town. They are not heard of again.

(REED, York, I, 69)

\section{Polstead (Suffolk)}

Sir John Howard made a gift of $2 s$ to the minstrels of Polstead on 13 August 1463 . This would not be a miscellaneous group, but not necessarily civic minstrels, either. The sum of $2 s$ suggests minstrels that he recognized.

(Botfield, Manners, 217: calendared in Rastall, 'Secular Musicians', II, 150)

\section{Poole (Dorset)}

A payment by the town in 1512/13 for 'the serjeant's board and his gown, and for the minstrels ...' suggests that Poole employed civic minstrels before 1512. Payments in 1515/16 and 1516/17 to a minstrel and a piper, respectively, show that the town had someone going about the town mornings and evenings. This may have been a dual minstrel and watchman duty, as in other ports, and perhaps considerably earlier than 1515.

(REED, Dorset and Cornwall, 239)

\section{Reading (Berkshire)}

In the period 1413-20 payments were made for minstrels' clothing: $10 \mathrm{~s} 6 \mathrm{~d}$ for two minstrels in 1413/14, and $5 s$ for an unspecified number (just one?) in 1419/20. The accounts for $1420 / 21$ include $10 s 7 d$ for livery to the common piper and his servants (communi ffistulatori et famulis suis), while in 1421/2 payment of $10 \mathrm{~s}$ was made for the livery of more than one piper and their servants (communis fistulatoris et serviencium suorum). No more such payments are found in the surviving records.

Reading thus appears to have employed two minstrels in 1413/14, a single piper in $1419 / 20$ and $1420 / 21$, and two or more pipers in 1421/2.

(REED, Berkshire)

\section{Rye (Sussex)}

A payment (Datum in remuniacione) to '[the] minstrels of the town' in 1479/80 must be for civic minstrels, confirmed by records in English from 1482/3 onwards. The record of a payment in early 1486 calls them 'the waytes of this Town'. Payment of $6 s 8 d$ for 'gown cloth' in late 1487 or early 1488 would be for two minstrels at most.

(REED, Sussex)

\section{Salisbury (Wiltshire)}

The Winchester accounts for $1394 / 5$ record a payment of $18 d$ to three minstrels of Salisbury, perhaps too small a reward for a group of civic minstrels. The royal records show that the king rewarded 'the 
waytes of Salisbury' with $6 s 8 d$ (a standard royal reward for liveried minstrels) in 1496, and again in 1505. ${ }^{101}$

(REED, Winchester and Hampshire, 1377-1420)

\section{Sandwich (Kent)}

Sandwich had a special version of the night marches of civic minstrels seen elsewhere as calling the hours. In the mid-1460s it was apparently customary for players of stringed instruments and trumpets (fidicines and tubicines) to march through the town announcing the state of the wind. ${ }^{102}$ The trumpeters (or hornblowers?) would certainly have been employees of the town, but not necessarily civic minstrels as such: the string-players might be regarded with some scepticism.

Town minstrels may have existed at Sandwich as early as 1444/5, when Christ Church Canterbury gave $2 s 0 d$ 'to [the] minstrels of Sandwich' (datum Ministrallis de Sandewico), but the first certain record of them is for cloth liveries in 1462/3. The town accounts for $1465 / 6$ record that the minstrels received $41 / 2$ yards of red cloth and musterdeviller (grey woollen cloth) at $2 s 6 d$ a yard, totalling $11 s 3 d$. While this was quite expensive material, the length suggests no more than two tunics. In 1468/9 'pe waytes of pe town' took $16 s 0 d$ for their livery as well as $40 s 0 d$ for their wages, perhaps indicating that there were still only two of them.

Three 'waytes' were sworn in 1476/7. They are named as John Watson, William Watson and William Scarlett. The Watsons were Beverley spiculatores in 1467 and earlier. Scarlett soon moved to Canterbury.

Three unnamed waits took the year's wages and money for livery cloth in $1482 / 3$. No more is recorded about the waits in the years up to 1509/10, although between 1498 and 1508 payments were made to one Richard Jeffe for blowing the horn. Jeffe was not necessarily a minstrel.

The civic minstrels visited other towns, as one would expect: they were probably at New Romney in 1478/9 (solutum Mimis Sandwici 20d) and 1491/2 (in regardo Ministrallis de Sandewiche 8d), and at Dover in 1487/8 (to 'the Mynstrellis of Sandwich' 20d), 1489/90 ('to the waytes of Sandwych' 20d), and $1492 / 3$ ('to the mynstrelles of Sandwich' 12d). The king rewarded 'the mynstrells of Sandwich' with 10s $0 d$ on 24 September $1492 .^{103}$

(REED, Kent, Diocese of Canterbury, II, passim; Dawson, 'Kent', 29, 30 and 125)

\section{Shrewsbury (Shropshire)}

The town employed two minstrels by $1432 / 3$, when liveries were made to them, but there were three 'waits of the town and community' (Weytes ville et communitatis) in 1435/6. There were again only two of them in 1437/8 and 1438/9. Three waits received liveries in 1441/2 and 1442/3, and between 1446/7 and 1509/10 (records for some years are missing).

The waits had scutcheons before 1463/4: records of the annual check on these, which alone provide information on the minstrels' names, are not very helpful. In 1505/6 pledges were given on behalf of William Breese, wait. ${ }^{104}$ On 18 December 1508/9 collars were delivered to the minstrels William Hethe, William Force and John Eton. William Force left the waits during the year, one of the guarantors for his collar being Richard Furbur, a harper.

(REED, Shropshire, 131-69, passim.)

\footnotetext{
${ }^{101}$ Ashbee, Records, VII, 156 and 178, from TNA E101.414.6, fol. $42^{\mathrm{r}}$ and BL Add. MS 21480, fol. $28^{\mathrm{r}}$. The Salisbury records are not yet available in REED (January 2021).

${ }^{102}$ Leo of Rozmital, Travels, 50.

${ }^{103}$ Ashbee, Records, VII, 152, from BL Add. MS 7099, fol. $7^{\mathrm{r}}$.

${ }^{104}$ Perhaps the Breese who was a Coventry wait in 1481; he would presumably be in his mid-40s or older in 1505/6. Coventry and Shrewsbury are about 60 miles apart.
} 


\section{Southampton (Hampshire)}

The three 'ministralli de Hampton' who performed at Winchester in 1394/5 may have been civic minstrels of Southampton. Their reward of $18 d$ is commensurate with other rewards given by Winchester to liveried minstrels. The first certain appearance of Southampton's civic minstrels in the town's records is not until 1433/4. ${ }^{105}$ Expenses for a feast on 13 January 1434 include a reward of $20 d$ to 'minstrels of Winchester who are now at Southampton', and the wife of one of them, Richard March, was paid $8 d$ for unspecified work on that day. The three minstrels took wages on 16 January, when payment was also made for liveries for 'the minstrels of Southampton'. They may have transferred from Winchester without obtaining permission, for the mayor of Winchester had all three of them - Richard March, John Goddislond and William Goldfynch - arrested, and Southampton's steward attended the assizes at Winchester to stand surety for them. Officials of Southampton then met with those of Winchester to discuss the matter.

Winchester apparently released the minstrels to Southampton. They are named as Richard Wayte, John Wayte and William Wayte (presumably March, Goddislond and Goldfynch), evidently a threeman shawm-band. The minstrels then disappear from the records until 1478/9, when cloth liveries were provided for three 'waytus of the towne', one of whom was John Jane (or Jay). One Robart Mydulton, who follows Jane/Jay in the list of liveries, may also have been a town minstrel. The (unnamed) waits next appear in the records for 1482/3, when liveries were given to only two minstrels. After another gap the accounts for 1492/3 show that three 'waytes of the town' received livery, and an unspecified number in 1495 (but at $20 s 0 d$ on both occasions).

(REED, Winchester and Hampshire, 1377-1420)

\section{Stamford (Lincolnshire)}

The Corporation elected and swore in three minstrels in $1472 / 3$, and did so in subsequent years for which records remain. Their names are shown in Table 5 . There is no indication that the minstrels were newly instituted in 1472 . The record of the swearing-in for 1479/80 shows that pledges were taken, and that for 1486/7 is explicit in stating that the pledges were taken for scutcheons (scuta), but no names are recorded.

The minstrel John Brandon was admitted a burgess on 5 December 1494. He was probably not a wait, but there is no record of the waits' names for 1494/5.

(REED, Lincolnshire)

\section{Walsingham (Norfolk)}

The waits of Walsingham were given $5 s 0 d$ by the king on 8 May 1506 .

(Ashbee, Records, VII, 180, from TNA E36.214, 58)

Table 5. The town minstrels of Stamford, 1472-87

\begin{tabular}{llll}
\hline $1472 / 3$ & William Barton & Christopher Totyll & Richard Pynder \\
\hline $1479 / 80$ & Henry Haynes & Richard Pyndell & William Johnson \\
\hline $1482 / 3$ & Henry Hede & Richard Pynder & William Smyth \\
\hline $1486 / 7$ & Henry Hayn & Richard Pynder & Christopher Totyll \\
\hline
\end{tabular}

\footnotetext{
${ }^{105}$ The town may have employed musicians much earlier, as Winchester's chamberlains gave $18 d$ to three ministrallis de Hampton in 1394/5. They could have been independent minstrels, however.
} 


\section{Wells (Somerset)}

In 1409/10 Philip Piper and William Godyer, minstrels, were elected and admitted burgesses of the town and sworn in as civic servants (presumably, although not certainly, as town minstrels). ${ }^{106}$

(REED, Somerset, 242)

\section{Winchelsea (Sussex)}

The accounts of Battle Abbey for $c 1478-82$ record a payment of $3 s 4 d$ to one or more minstrels of Winchelsea (hist' de Wynchilse) at Christmas. The reward would be adequate for several civic minstrels, but the accounts of Winchelsea do not survive from so early and the existence of civic minstrels cannot be confirmed.

(REED, Sussex)

\section{Winchester (Hampshire)}

Winchester's ministralli civitatis were given cloth liveries in $1397 / 8$, when the town paid $16 s 8 d$ for $81 / 2$ yards of striped cloth and $5 \frac{1 / 2}{2}$ yards of a one-colour cloth, a total of 14 yards of cloth. Southampton allowed two yards of broadcloth for each minstrel in 1478/9, and 51/2 yards of broadcloth each in 1482/3, so Winchester's 14 yards could indicate a group of three minstrels.

An unspecified number of town minstrels received livery costing $16 s \mathrm{~d}$ in $1406 / 7$. Judging by later costs this was probably for three minstrels: tunics for three minstrels cost $17 s 8 d$ in $1432 / 3$ and $15 s 10 d$ in 1446/7. In 1434 the Winchester waits-Richard March, John Goddislond and William Goldfynch-were released to Southampton: they were apparently replaced within two or three years, but the incomers' names are not recorded.

(REED, Winchester and Hampshire, 1377-1420)

\section{York}

The City Chamberlains' account-roll for 1433 is the earliest surviving from the fifteenth century, and the earliest appearance of the York waits. It records liveries for three city minstrels (called 'Waytes' in the margin), as do payments for liveries in 1442, 1445 and on into the sixteenth century (the last that concerns us here dates from 1508). Survival of the chamberlains' accounts is patchy, so that there may have been fluctuations in the number of minstrels: but three of them is the only number in surviving records and was apparently the norm. With only three exceptions their names are not given.

In 1486 Robert Sheyne retired after service of forty years or more as a York wait, being then too old for the post. ${ }^{107} \mathrm{He}$ was presumably the former Beverley spiculator (1433-6). In recognition of his long service, the city awarded Sheyne a pension and the use of a house for his lifetime, free of charge. The pension was not provided by the city, however: $13 s 4 d$ (one mark) per annum was to be paid in quarterly instalments by Sheyne's successor, Robert Comgilton, during Sheyne's life and for as long as Comgilton was a York wait.

This is an unusual, perhaps unique, arrangement, and it argues for special circumstances. A Robert Congilton was appointed spiculator at Beverley in 1440, leaving that post by 1443, but a gap of 43 years (1443-1486) casts doubt on the York wait being the same man. Apart from the question of Congilton's career in that period, there is the matter of his age: if he was 18 or so on appointment at Beverley (after apprenticeship), he would be around 64 on appointment at York.

There is clearly another story behind these facts, apparently linking the two men in their careers. Comgilton's provision of an annuity, if puzzling, argues for an indebtedness to Sheyne, perhaps for his

\footnotetext{
${ }^{106}$ A William Goodyere was a royal trumpeter, 1447-68: Rastall, 'Secular Musicians', II, 127-30, passim. He cannot be the same man, but perhaps a son or other relative of the Wells minstrel.

${ }^{107}$ REED, York, I, 143: order of 4 October 1486; Raine, York, I, 170.
} 
post, or for earlier patronage. Certainly it suggests a strong and perhaps long-standing link between the two men. If Comgilton was indeed the Beverley minstrel of the early 1440s an obvious possible link would be that Sheyne was Congilton's master during the latter's apprenticeship in the 1430s. It is also possible that the York Comgilton was the Beverley wait's son, named after his father; and as the two men bore the same Christian name, Sheyne may have been godfather to Congilton.

Sheyne's pension was part of a financial deal struck between Comgilton and the city. One mark per annum was not a living income, but the money was probably not all that stood between Sheyne and starvation. A town wait might well earn enough during his career to save a useful sum against retirement. Nor should we assume that without the house Sheyne would have nowhere to live. He could live in the house provided for his lifetime, but he would already own or rent suitable lodgings, when the city's house would be a means of income through letting.

The third named York wait is Roger Smalwood, who in 1505 made himself a scutcheon at a cost of $13 \mathrm{~s}$ 4d. Evidently Smalwood was a competent smith (initially a trained instrument-maker, perhaps?) as well as a minstrel.

(REED, York)

\section{Conclusions}

The map of the towns discussed here shows that civic minstrels had appeared all over England by 1509 . Some were apparently instituted surprisingly late, however, and even allowing for the loss of records, a range of reasons must be considered. The emergence of civic minstrels depended partly on the wealth of a town and its desire to take a prestigious place in the world - not just in trade and commerce, but also in charity, the well-being of its citizens, and its general culture. These last were not purely altruistic, since they fostered employment and trade, and brought prestige to the town. For local minstrels, employment as civic waits provided regular work, financial security, the respect due to a livery (including well-paid work independently of the town), and often security in retirement.

The civic minstrel establishment was almost entirely of a single minstrel or up to four of them. There is no indication that the number of waits employed, even when this fluctuated from year to year, depended on, or had any influence on, the kind of work that they did, which was primarily musical but may also have included announcements in some places. The number of waits employed may nevertheless point towards possible reasons for increases: a growing sense of civic pride, a wider geographical area to cover in the larger towns, expanding celebrations at the major feasts, and so on. Table 6 shows the earliest dates at which one can be fairly sure of the existence of civic minstrels and the number of them employed in various places. ${ }^{108}$ Following a steady emergence of civic bands through the fifteenth century there is a clear increase through the 1490s, perhaps related to the relatively stable government of Henry VII and a consequent increase in civic wealth after the civil war of the Roses.

As the table shows, all of the first five towns to employ minstrels were ports: three of them employed a single minstrel, and the other two employed three and four minstrels (Exeter and Bristol, respectively). There is no evolutionary process discernible: a single minstrel seems to have fulfilled the same duties as groups of two, three or four - fluctuating numbers were not uncommon, as the records show - and groups of two minstrels are found throughout the fifteenth century. Nor did the pipers transform from watchmen to musicians, for their description as vigiles or spiculatores sometimes post-dates the documents' use of ministralli or histriones (as at Canterbury and Exeter).

It is also easy to see that the majority of towns employed three minstrels. This ensemble probably consisted of two treble shawms and a tenor (or bombard). The tenor shawm was developed in the late fourteenth century and, according to the rather sparse iconographical and documentary evidence, became part of a standard loud wind band. When a fourth player was added, he was a trumpeter,

\footnotetext{
${ }^{108}$ The information given here is therefore conservative: the individual sections (above) will suggest earlier but not certain dates for the existence of civic minstrels.
} 
Table 6. Sizes of town minstrel groups. Key: FR = First reference; $1=$ solo minstrel; $2=$ two minstrels; $3=$ three minstrels; $4=$ four minstrels

\begin{tabular}{|c|c|c|c|c|}
\hline FR & 1 & 2 & 3 & 4 \\
\hline \multicolumn{5}{|l|}{$1361-1370$} \\
\hline Exeter $1362 / 3$ & Exeter 1362/3 & & & \\
\hline \multicolumn{5}{|l|}{ Dover 1365/6 } \\
\hline $1371-1380$ & Dover 1371 & & & \\
\hline \multicolumn{5}{|l|}{$1381-90$} \\
\hline \multicolumn{5}{|l|}{ ? Cambridge 1388/9 } \\
\hline \multicolumn{5}{|l|}{ ? Colchester 1390} \\
\hline \multicolumn{5}{|l|}{$1391-1400$} \\
\hline \multirow[t]{2}{*}{ Bristol 1391} & & & & Bristol 1391 \\
\hline & & & \multicolumn{2}{|l|}{ Exeter $1391 / 2$} \\
\hline Grimsby $1396 / 7$ & Grimsby1396/7 & & & \\
\hline \multicolumn{5}{|l|}{ Winchester 1397/8 } \\
\hline \multicolumn{5}{|l|}{$1401-1410$} \\
\hline Canterbury 1401/2 & & & \multicolumn{2}{|l|}{ Canterbury 1401/2 } \\
\hline Beverley $1405 / 6$ & & Beverley 1407/8 & & \\
\hline \multicolumn{5}{|l|}{ Norwich 1408} \\
\hline ? Wells 1409/10 & & Wells $1409 / 10$ & & \\
\hline \multicolumn{5}{|l|}{$1411-20$} \\
\hline \multirow[t]{3}{*}{ Reading 1413/14 } & & Reading $1413 / 14$ & & \\
\hline & & & Beverley 1416/17 & \\
\hline & & & Canterbury 1416/17 & \\
\hline \multicolumn{5}{|l|}{$1421-30$} \\
\hline & & & Grimsby $1421 / 2$ & \\
\hline Lincoln 1422 & & Norwich & Lincoln 1422 & \\
\hline \multirow[t]{4}{*}{ Coventry 1423} & & & & Coventry 1423 \\
\hline & & Dover $1423 / 4$ & & \\
\hline & & & Norwich 1426/7 & \\
\hline & & & Exeter $1427 / 8$ & \\
\hline \multicolumn{5}{|l|}{$1431-40$} \\
\hline Lynn 1431 & & & Lynn 1431 & \\
\hline Shrewsbury $1432 / 3$ & & Shrewsbury $1432 / 3$ & & Norwich $1432 / 3$ \\
\hline \multirow[t]{2}{*}{ York 1433} & & & York 1433 & \\
\hline & & & Winchester 1433/4 & \\
\hline Southampton $1433 / 4$ & & & Southampton $1433 / 4$ & \\
\hline
\end{tabular}


Table 6. Continued

\begin{tabular}{|c|c|c|c|c|}
\hline FR & 1 & 2 & 3 & 4 \\
\hline \multicolumn{5}{|l|}{ London $1334 / 5$} \\
\hline & & \multicolumn{3}{|c|}{ Shrewsbury $1435 / 6$} \\
\hline $1441-50$ & & & & London (9) 1442 \\
\hline \multicolumn{5}{|l|}{ ? Newcastle on T. 1445} \\
\hline \multicolumn{5}{|l|}{ ? Knaresborough 1446} \\
\hline ? Leicester 1447 & & & & Leicester 1447 \\
\hline Nottingham 1448 & & & Nottingham 1448 & \\
\hline \multicolumn{5}{|l|}{ ? Ash Priors 1448/9 } \\
\hline \multicolumn{5}{|l|}{$1451-60$} \\
\hline \multicolumn{5}{|l|}{ Hull 1454} \\
\hline \multicolumn{5}{|l|}{ Bridgwater 1455/6 } \\
\hline Doncaster 1457 & & Doncaster 1457 & & \\
\hline \multicolumn{5}{|l|}{$1461-70$} \\
\hline \multicolumn{5}{|l|}{ Sandwich $1462 / 3$} \\
\hline Ludlow 1466/7 & & Ludlow 1466/7 & & \\
\hline \multicolumn{5}{|l|}{ Calais $1467 / 8$} \\
\hline \multicolumn{5}{|l|}{$1471-80$} \\
\hline \multirow[t]{2}{*}{ Stamford $1472 / 3$} & & & Stamford $1472 / 3$ & \\
\hline & & & Sandwich $1476 / 7$ & \\
\hline \multicolumn{5}{|l|}{ ? Winchelsea c1478-82 } \\
\hline \multicolumn{5}{|l|}{ Rye $1479 / 80$} \\
\hline \multicolumn{5}{|l|}{$1481-90$} \\
\hline \multicolumn{5}{|l|}{ Chester $1484 / 5$} \\
\hline \multicolumn{5}{|l|}{ Oxford 1490/1 } \\
\hline \multicolumn{5}{|l|}{$1491-1500$} \\
\hline \multicolumn{5}{|l|}{ Maidstone 1492} \\
\hline \multicolumn{5}{|l|}{ Northampton 1493} \\
\hline \multicolumn{5}{|l|}{ Dartford 1494} \\
\hline \multicolumn{5}{|l|}{ Chichester 1496} \\
\hline \multicolumn{5}{|l|}{ Salisbury 1496} \\
\hline \multicolumn{5}{|l|}{ Plymouth 1496/7 } \\
\hline \multicolumn{5}{|l|}{ Hounslow 1498} \\
\hline Kingston on Th. 1498 & & & & \\
\hline
\end{tabular}


Table 6. Continued

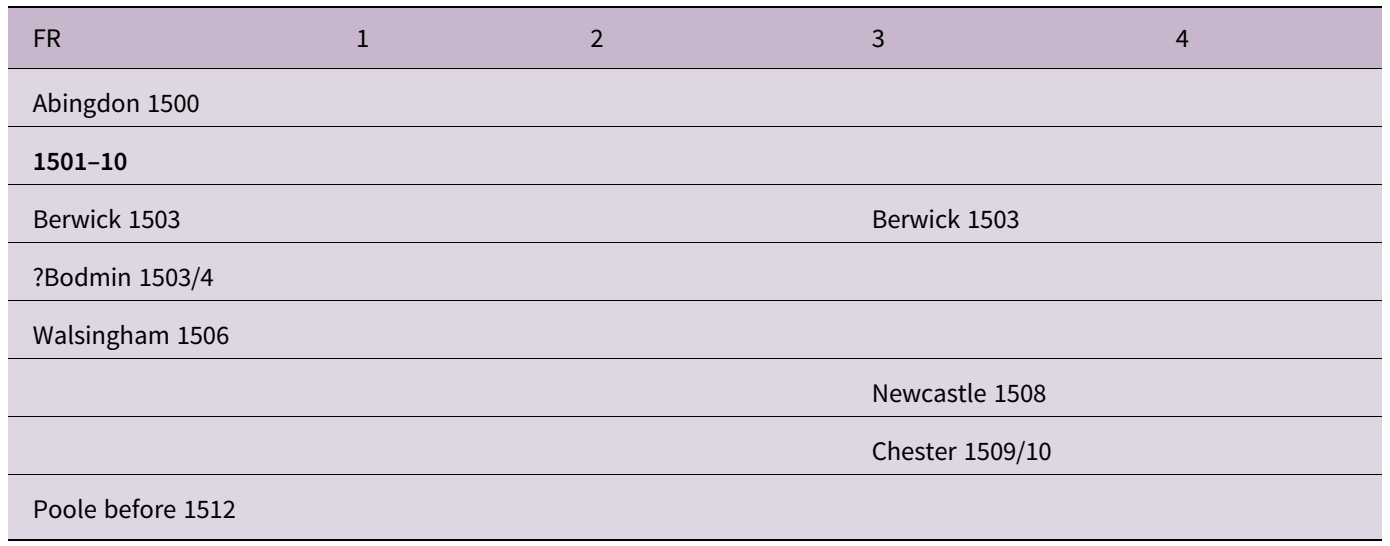

though again the evidence is sparse (see under Coventry). Probably this involved a single-slide instrument until the late fifteenth century and a double-slide instrument (sackbut) thereafter. ${ }^{109}$

This study raises many questions about the musical repertory, the instrumentation involved, the exact nature of the occasions of civic minstrelsy and what part the minstrels played in various celebrations. These are also related to questions concerned in studies of minstrelsy in royal and aristocratic households. The evidence is sparse, as always, and explorations of it are reserved for another occasion. ${ }^{110}$

\section{Bibliography}

K. J. Allison, ed., A History of the County of York, East Riding VI: The Borough and Liberties of Beverley. Victoria County History (Oxford: Oxford University Press for the Institute of Historical Research, 1989)

Andrew Ashbee, Records of English Court Music. 9 vols. (Aldershot, Scolar Press, 1986-96)

Mary Bateson, Records of the Borough of Leicester (London and Cambridge, 1899)

Beriah Botfield, ed., Manners and Household Expenses of the 13th and 15th Centuries (London, 1841)

Joseph C. Bridge, 'Town waits and their tunes'. Proceedings of the Musical Association, 54 (1927-8), 63-92

BL British Library, London (with call-number)

Calendar of the Patent Rolls (CPR) Preserved in the Public Record Office (London, 1891-)

Henry S. Cobb, 'Cinque Ports'. Paul E. Szarmach, M. Teresa Tavormina and Joel T. Rosenthal, eds. Medieval England: An Encyclopedia (New York and London, Garland Publishing, Inc., 1998), 188

Victor Coelho and Keith Polk. Instrumentalists and Renaissance Culture, 1420-1600 (Cambridge: Cambridge University Press, 2016)

Giles E. Dawson, Records of Plays and Players in Kent, 1450-1642, Malone Society Collections, 7 (Oxford: Oxford University Press for the Malone Society, 1965)

T. Dickson and J. B. Paul, eds, Accounts of the Lord High Treasurer of Scotland, Vols. I and II (Edinburgh: H. M. General Register House, 1877, 1900)

C. M. Fraser, Accounts of the Chamberlains of Newcastle upon Tyne, 1508-1511 (Society of Antiquaries of Newcastle upon Tyne, 1987)

Alice Green, Town Life in the Fifteenth Century (London: Macmillan \& Co., 1894)

Mary Dormer Harris, The Coventry Leet Book (London: Early English Text Society, 1907-13)

Historical Manuscripts Commission (HMC). Publications of the Royal Commission on Historical Manuscripts 5th Report (London, Her Majesty's Stationery Office, 1876)

_-_. Publications of the Royal Commission on Historical Manuscripts, 54th Report (London, Her Majesty's Stationery Office, 1900)

W. Hudson and J.C. Tingey, The Records of the City of Norwich (Norwich and London: Jarrold \& Sons, 1906-1910)

\footnotetext{
${ }^{109}$ Performance practice is outside the scope of this article, but see Rastall and Taylor, Minstrels and Minstrelsy, ch. 14 and 15 , passim.

${ }^{110}$ Rastall and Taylor, Minstrels and Minstrelsy, forthcoming.
} 
Carole Ann Janssen, 'The Waytes of Norwich in Medieval and Renaissance Civic Pageantry' (Ph.D. dissertation, University of New Brunswick, 1978)

Stanley J. Kahrl, Records of Plays and Players in Lincolnshire, Malone Society Collections, 8 (Oxford: Oxford University Press for the Malone Society, 1974)

M. R. Lambert and M. S. Sprague, Lincoln (Oxford: Basil Blackwell, 1933)

Ian Lancashire, “Ioly Walte and Malkyng”: A Grimsby Puppet Play in 1431'. Records of Early English Drama Newsletter, 1979/2, 6-8

A. F. Leach, Beverley Town Documents (London: Bernard Quaritch for the Selden Society, 1900)

- - Report on the Manuscripts of the Corporation of Beverley (London, 1900)

Leo of Rozmital, The Travels of Leo of Rozmital through Germany, Flanders, England, France, Spain, Portugal and Italy, 1465-1467, ed. Gabriel Tetzel and Václav Šašek (Cambridge: Cambridge University Press for the Hakluyt Society, 1957)

James Merryweather, 'The Minstrels' Pillar in St. Mary's Church, Beverley - a Tudor portrait of the York waites?' <www. townwaits.org.uk/essays_index.shtml/essays_stmarys.shtml> (accessed 26 October 2020)

Gerard Nijsten, Het Hof van Gelre: Cultuur ten tijde van de hertogen uit het Gulikse en Egmondse huis (1371-1473) (Kampen: Kok Agora, 1992; trans. by Tanis Guest as In the Shadow of Burgundy: the Court of Guelders in the Late Middle Ages (Cambridge: Cambridge University Press, 2004)

Arthur Oswald, 'The Town Waits'. Country Life (1952)

The Oxford Dictionary of National Biography <https://www.oxforddnb.com>

George Poulson, Beverlac, or, The Antiquities and History of ... Beverley (London: G. Scaum, 1829)

A. Raine, ed., York Civic Records. 2 vols. (York: Yorkshire Archaeological Society 1939-1941)

G. R[ichard] Rastall, 'Secular Musicians in Late Medieval England'. 2 vols. (Ph.D. dissertation, University of Manchester, 1968). <http://www.townwaits.org.uk/essays_index.shtml>

Richard Rastall, 'Minstrels and Players: Functions and Terminology'. Romard 55 (2016), 81-92

- - . 'The Minstrels of the English Royal Households: An Inventory', Royal Musical Association Research Chronicle 4 (1967), $1-41$.

Richard Rastall and Andrew Taylor. Minstrels and Minstrelsy in Late Medieval England. (Woodbridge: Boydell and Brewer, forthcoming)

REED Records of Early English Drama

REED Berkshire (ed. Alexandra F. Johnston). Online, 2018

REED Cambridge (ed. Alan H. Nelson). 2 vols. Toronto, University of Toronto Press, 1989

REED Cheshire, including Chester (ed. Elizabeth Baldwin, Lawrence M. Clopper and David Mills). 2 vols. Toronto, University of Toronto Press, and London, The British Library, 2007

REED Coventry (ed. R.W. Ingram). Toronto, Toronto University Press, 1981

REED Cumberland, Westmorland and Gloucestershire (ed. Audrey Douglas and Peter Greenfield). Toronto, University of Toronto Press, 1986

REED Devon (ed. John M. Wasson). Toronto, University of Toronto Press, 1986

REED Dorset and Cornwall (ed. Rosalind Conklin Hays, C.E. McGee, Sally L.K. Joyce and Evelyn S. Newlyn). Toronto, University of Toronto Press, and Turnhout, Brepols Publishers, 1999

REED Hampshire see Winchester and Hampshire

REED Kent: Diocese of Canterbury (ed. James M. Gibson). 3 vols. Toronto, University of Toronto Press, and London, The British Library, 2002

REED Lincolnshire (ed. James Stokes). 2 vols. Toronto, Toronto University Press, and London, The British Library, 2009

London REED Civic London to 1558 (ed. Anne B. Lancashire). 3 vols. Cambridge, D. S. Brewer, 2015

REED Ecclesiastical London (ed. Mary C. Erler). Toronto, University of Toronto Press, and London, The British Library, 2008

REED Newcastle upon Tyne (ed. J.J. Anderson). Toronto, Toronto University Press, and Manchester, Manchester University

Press, 1982

REED Oxford (ed. John R. Elliott Jr, Alan H. Nelson, Alexandra F. Johnston and Diana Wyatt). 2 vols. Toronto, University of

Toronto Press, and London, The British Library, 2004

REED Shropshire (ed. J. Alan B. Somerset). 2 vols. Toronto, University of Toronto Press, 1994

REED Somerset including Bath (ed. James Stokes and Robert J. Alexander). 2 vols. Toronto, University of Toronto Press, 1996

REED Sussex (ed. Cameron Louis). Toronto, University of Toronto Press, 2000

REED Winchester and Hampshire (ed. Jane Cowling and Peter Greenfield). Online, 2019

REED York (ed. Alexandra F. Johnston and Margaret Rogerson). 2 vols. Toronto, University of Toronto Press, and

Manchester, Manchester University Press, 1979

REED Yorkshire: East Riding (ed. Diana Wyatt). Forthcoming

G. A. Stephen, 'The Waits of the City of Norwich'. Norfolk Archaeology 25 (1933)

W. H. Stevenson and W. T. Baker, eds, Records of the Borough of Nottingham (London and Nottingham: London, Bernard Quaritch, and Nottingham, Thomas Forman \& Sons, 1882-1900

James Stokes, 'The Waits of Lincolnshire', Early Theatre 1 (1998), 75-111 
TNA The National Archives, Kew

Waits (International Guild of Town Pipers) Accessed 26 May 2021. <http://www.townwaits.org.uk/history_doncaster.shtml> H. F. Westlake, The Parish Gilds of Medieval England (London: Society for Promoting Christian Knowledge (SPCK), 1919)

Eila Williamson, 'The Cult of the Three Kings of Cologne in Scotland', in Steve Boardman, John Reuben Davies and Eila Williamson, eds, Saints' Cults in the Celtic World (Woodbridge: The Boydell Press, 2009), 160-79

Walter L. Woodfill, Musicians in English Society from Elizabeth to Charles I (Princeton NJ, 1953; repr. New York: Princeton University Press; (repr.) Da Capo Press, 1969)

Diana Wyatt, 'Performance and Ceremonial in Beverley before 1642' (Ph.D. dissertation, University of York, 1983) 